\title{
Risks and opportunities of increasing yields in organic farming. A review
}

\author{
Elin Röös ${ }^{1}$ (1) - Axel Mie ${ }^{2} \cdot$ Maria Wivstad $^{3} \cdot$ Eva Salomon $^{4} \cdot$ Birgitta Johansson $^{5} \cdot$ Stefan Gunnarsson ${ }^{5}$. \\ Anna Wallenbeck ${ }^{5,6} \cdot$ Ruben Hoffmann $^{7} \cdot$ Ulf Nilsson $^{8} \cdot$ Cecilia Sundberg $^{9} \cdot$ Christine A. Watson $^{10,11}$
}

Accepted: 5 February 2018 / Published online: 27 February 2018

(C) The Author(s) 2018. This article is an open access publication

\begin{abstract}
Current organic agriculture performs well in several sustainability domains, like animal welfare, farm profitability and low pesticide use, but yields are commonly lower than in conventional farming. There is now a re-vitalized interest in increasing yields in organic agriculture to provide more organic food for a growing, more affluent population and reduce negative impacts per unit produced. However, past yield increases have been accompanied by several negative side-effects. Here, we review risks and opportunities related to a broad range of sustainability domains associated with increasing yields in organic agriculture in the Northern European context. We identify increased $\mathrm{N}$ input, weed, disease and pest control, improved livestock feeding, breeding for higher yields and reduced losses as the main measures for yield increases. We review the implications of their implementation for biodiversity, greenhouse gas emissions, nutrient losses, soil fertility, animal health and welfare, human nutrition and health and farm profitability. Our findings from this first-of-its-kind integrated analysis reveal which strategies for increasing yields are unlikely to produce negative side-effects and therefore should be a high priority, and which strategies need to be implemented with great attention to trade-offs. For example, increased $\mathrm{N}$ inputs in cropping carry many risks and few opportunities, whereas there are many risk-free opportunities for improved pest control through the management of ecosystem services. For most yield increasing strategies, both risks and opportunities arise, and the actual effect depends on management including active mitigation of side-effects. Our review shows that, to be a driving force for increased food system sustainability, organic agriculture may need to reconsider certain fundamental principles. Novel plant nutrient sources, including increased nutrient recycling in society, and in some cases mineral nitrogen fertilisers from renewable sources, and truly alternative animal production systems may need to be developed and accepted.
\end{abstract}

Keywords Organic agriculture $\cdot$ Yield $\cdot$ Biodiversity $\cdot$ Soil fertility $\cdot$ Animal welfare $\cdot$ Nutrition $\cdot$ Environment

Elin Röös

elin.roos@slu.se

1 Department of Energy and Technology, Swedish University of Agricultural Sciences, Uppsala, Sweden

2 Department of Clinical Science and Education, Södersjukhuset, Karolinska Institutet, Stockholm, Sweden

3 EPOK-Centre for Organic Food and Farming, Swedish University of Agricultural Sciences, Uppsala, Sweden

4 Swedish Institute of Agricultural and Environmental Engineering, Uppsala, Sweden

5 Department of Animal Environment and Health, Swedish University of Agricultural Sciences, Skara, Sweden
6 Department of Animal Breeding and Genetics, Swedish University of Agricultural Sciences, Uppsala, Sweden

7 Department of Economics, Swedish University of Agricultural Sciences, Uppsala, Sweden

8 Department of Ecology, Swedish University of Agricultural Sciences, Uppsala, Sweden

9 Department of Sustainable Development, Environmental Sciences and Engineering, Royal Institute of Technology, Stockholm, Sweden

10 Department of Crop Production Ecology, Swedish University of Agricultural Sciences, Uppsala, Sweden

11 SLU and Crop and Soil Systems Research Group, Scotland's Rural College, Craibstone Estate, Aberdeen, UK 


\section{Contents}

1 Introduction

2 Yields in organic production

2.1 Crop production

2.2 Livestock production

3 Risks and opportunities associated with increasing yields in organic production

3.1 Biodiversity

3.2 Emissions of greenhouse gases

3.3 Nutrient losses

3.4 Soil fertility

3.5 Animal health and welfare

3.6 Human nutrition and health

3.7 Farm profitability

4 Summary and reflections

References

\section{Introduction}

Consumer demand for organic products has increased dramatically in the recent past, with global sales increasing more than threefold (although from low levels) since the turn of the century (Reganold and Wachter 2016). Some countries in Northern Europe are currently witnessing a boom in sales of organic foods. In Sweden, sales increased by $18 \%$ in 2016 compared with the previous year, with organic products now constituting $8.7 \%$ of total food sales (Ekoweb 2017).

Organic agriculture emerged as a reaction to the industrialisation of agriculture and its associated environmental and social problems. Whether organic agriculture actually delivers overall advantages over conventional agriculture is however contentious. Some claim that organic farming systems are more profitable and environmentally friendly (Reganold and Wachter 2016), while others question the role of organic agriculture in future sustainable food systems (Connor and Mínguez 2012).

The main criticism of organic agriculture is its lower productivity at a time when food production has to increase substantially to feed a growing, more affluent global population. Critics consider organic agriculture inefficient, especially in terms of land use. With the rising global demand for food, they point out that current agricultural land will not suffice and further expansion of agricultural land into pristine ecosystems will result from the expansion of organic agriculture (Kirchmann et al. 2009, Connor and Mínguez 2012). Others suggest that 'ecological intensification' of crop production systems, i.e. utilisation and management of ecosystem services delivered by biodiversity, rather than anthropogenic inputs, is the best option to sustainably meet future food demand while reducing environmental pressures (Bommarco et al. 2013; Ponisio et al. 2015).
Controversies aside, both critics and many proponents of organic agriculture share the common view that yields in organic agriculture have to increase. For the organic movement, the Organic 3.0 initiative (the next stage of development in organic farming) has reignited the debate on the need to increase yields, as it includes an ambition for organic farming to be considered a major, rather than a niche, solution to sustainable farming (IFOAM 2015). Others highlight the need for organic agriculture to increase yields in order to become more 'environmentally efficient' since, although organic agriculture is usually associated with lower environmental burdens per hectare compared with conventional farming, adverse impacts are often similar or higher on a per kilogram of product basis due to lower outputs (Clark and Tilman 2017).

According to its principles, the aims of organic farming go beyond food production to include caring for and protecting the environment (landscapes, climate, habitats, biodiversity, air and water) and the wellbeing of people and animals (IFOAM 2005). It is thus highly relevant to enquire how a focus on increased yields will affect reaching these wider goals. Seufert and Ramankutty (2017) provide the latest comprehensive review on the costs and benefits of organic agriculture in its current form and conclude that, on the positive side, organic agriculture delivers higher biodiversity and improved soil and water quality per unit area, enhanced profitability and higher food nutritional value. On the negative side, there are many costs, including lower yields and higher consumer prices. How will this change when different strategies to increase yields are implemented?

The aim of this review is to shed some light on this question. We highlight and analyse possible risks and opportunities related to a broad range of sustainability aspects when aiming to increase yields in organic agriculture. As organic agriculture varies considerably across the globe, we focus our analysis to the context of Northern Europe, using examples from Sweden to illustrate our case. We end this review by summarising our findings and critically reflecting on how organic practices based on current EU regulations (EU 2014) affect the possibility of sustainably increasing yields.

The review is structured as follows. Chapter 2 provides the background and includes an overview of organic yields compared with conventional yields, including an outline of factors that limit yields, and strategies to increase yields in organic agriculture. Chapter 3 summarises how striving for increased yields in organic production could affect the following areas: biodiversity, emissions of greenhouse gases (GHG), nutrient losses, soil fertility, animal welfare and health, human nutrition and health, and farm profitability (Fig. 1). For each topic, we start with a brief introduction to the area to cater for the wide audience of this paper due to its broad coverage and to justify inclusion of the area in the review. Based on published research, we then discuss and critically reflect upon how increasing yields through increased inputs, genetic 
Fig. 1 Structure of the review performed in this study

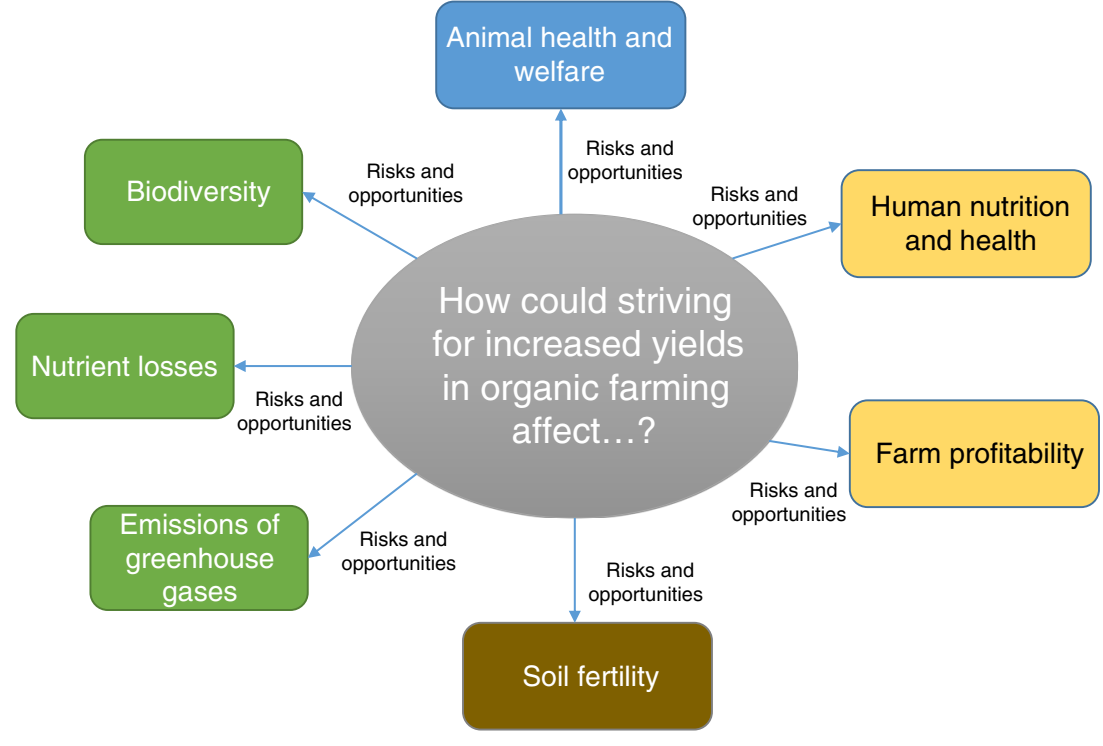

improvement and applying best available management practices will affect this area. The overarching conclusions from the review are summarised and discussed in Chapter 4.

In this review, we use the following definitions of yield commonly used in practice and in research, e.g. in field trials, breeding, evaluation of feeding strategies, production metrics etc. For crop production, the yield is defined as the amount of crop harvested from the field per unit area and year. As for livestock production, the yield concept is more complex and commonly include both production per animal and time and feed use (amount and type) to produce one unit of animal product; here we include both in our discussion.

\section{Yields in organic production}

\subsection{Crop production}

Recent meta-analyses with global coverage show that organic crop yields are on average $80 \%$ (de Ponti et al. 2012), 66-95\% (Seufert et al. 2012) or $81 \%$ (Ponisio et al. 2015) of conventional yields. Yield differences vary considerably with growing conditions, management practices and crop types, with legumes showing a considerably smaller yield gap than cereals or tubers. Based on 34 studies from Sweden, Finland and Norway, de Ponti et al. (2012) found that organic yields in this region are $70 \%$ of conventional yields. Yield statistics for Sweden from 2015 show that organic cereal yields in that year ranged between 53\% (winter rye and winter wheat) and 58\% (spring wheat) of conventional yields. Organic leguminous crops yielded $69 \%$ (peas) and $87 \%$ (field beans) of conventional crop yields and organic leys $87 \%$ of conventional yields. These values represent national averages for organic and conventional production, but geographical bias, which is present because there are more organic farms in regions less favourable for cropping, is not accounted for (SS 2016).

Supply of nitrogen $(\mathrm{N})$ and control of perennial weeds are two of the most important yield-limiting factors in organic crop production (Askegaard et al. 2011). These are linked, as sufficient $\mathrm{N}$ availability for rapid early establishment and growth of crops also has a strong influence on reducing weed infestation, by greater weed suppression ability of the crop (Olesen et al. 2007). Commonly used organic fertilisers such as manure, compost, green manure and organic wastes are low in plant-available $\mathrm{N}$ and this, in combination with slow $\mathrm{N}$ mineralisation in the spring due to low temperatures, restricts yields in organic crops, especially in the Nordic countries (Dahlin et al. 2005).

Yield losses due to pests and disease also affect the organic-conventional yield gap. The number of crop protection products approved for organic agriculture is very limited (EU 2014), and although they constitute an important input for reducing crop losses, especially in some horticultural crops (Letourneau and van Bruggen 2006), the lack of crop protection products or other effective crop protection measures limits organic yields. We should stress here that, although copper-based products are among the most widely used crop protection products in European organic farming and are important for controlling fungus attacks in, e.g. vines, fruit crops and potatoes (Niggli et al. 2016), copper fungicides are prohibited in Scandinavian countries by national legislation.

Organic farmers frequently have to rely on plant varieties bred for high-input conventional systems, i.e. high-yielding varieties with e.g. poor weed competitive abilities and shallower rooting depth (Lammerts van Bueren et al. 2011). In conventional production systems, these deficits are rectified by the use of herbicides and inorganic nutrients. 
Table 1 Strategies to increase yields in organic arable crops that are applicable to Northern Europe. Adapted from Niggli et al. (2016)

\begin{tabular}{|c|c|c|}
\hline $\begin{array}{l}\text { Area of } \\
\text { intervention }\end{array}$ & Important for & Strategies to increase yields \\
\hline Soil fertility & All crops, but especially on stockless farms & $\begin{array}{l}\text { - Crop rotation design and management including optimal management of legume } \\
\text { pre-crop effects and green manure crops } \\
\text { - Increased crop diversity } \\
\text { - Intercropping } \\
\text { - New technologies for reduced tillage } \\
\text { - Increased cooperation between livestock farms and stockless farms } \\
\text { - Adding/promoting supportive microorganisms and fungi in soil }\end{array}$ \\
\hline Plant nutrients & All crops (except nitrogen for legumes) & $\begin{array}{l}\text { - Optimal use of legumes in rotations } \\
\text { - Effective use of manures } \\
\text { - Increased recycling and use of nutrients from society } \\
\text { - Novel treatments of organic food wastes to produce high-quality composts } \\
\text { - Technological solutions for safe sewage sludge treatments and recycling }\end{array}$ \\
\hline $\begin{array}{l}\text { Crop-weed } \\
\text { competition }\end{array}$ & $\begin{array}{l}\text { All crops, but especially in stockless systems } \\
\text { without perennial leys }\end{array}$ & $\begin{array}{l}\text { - Crop rotation design and management } \\
\text { - New physical weed control strategies and techniques including cover crop } \\
\text { management } \\
\text { - Use of the false seedbed technique } \\
\text { - Precision farming and robots }\end{array}$ \\
\hline $\begin{array}{r}\text { Control of } \\
\text { diseases }\end{array}$ & All crops, but especially potatoes and legumes & $\begin{array}{l}\text { - Use of tolerant or resistant crop varieties } \\
\text { - Crop rotation design and management } \\
\text { - Preventative strategies like intercropping, deep ploughing, optimal planting date etc. } \\
\text { - New techniques and products for preventing fungal infections, physical methods } \\
\text { and biocontrol organisms } \\
\text { - Replace copper that is currently used } \\
\text { - Use of certified and dressed seeds }\end{array}$ \\
\hline Control of pests & $\begin{array}{l}\text { All crops, several pests in oilseed rape and } \\
\text { potatoes }\end{array}$ & $\begin{array}{l}\text { - Crop rotation design } \\
\text { - Habitat manipulation (hedgerows, wild flower strips etc.) to strengthen functional } \\
\text { biodiversity (e.g. natural enemies) } \\
\text { - Physical/biological methods like nets, traps and repellents } \\
\text { - Selective pest control products with low negative side-effects }\end{array}$ \\
\hline
\end{tabular}

To overcome these limiting factors, a number of strategies are available. Niggli et al. (2016) describe many of these for arable crops, summarised here in Table 1. Some of the strategies involve implementation of well-known best practices, e.g. the use of favourable crop rotation design to prevent weed infestation and disease and pest outbreaks. Others require more research and development, e.g. how to manipulate surrounding landscapes to strengthen functional biodiversity and the use of new fertiliser sources, crop protection products and techniques. Furthermore, changes in the EU organic regulations are needed to implement some of the proposed strategies.

Concerning horticultural crops, which are susceptible to many pests and pathogens (Letourneau and van Bruggen 2006), new crop protection strategies and development and increased use of a variety of biological control agents (e.g. bacteria, fungi and predatory arthropods) (van Lenteren 2012) will be particularly important to reduce the yield gap. Increased use of resistant varieties is also crucial (Speiser et al. 2006), but these varieties are however not fully resistant, implying that direct crop protection measures will be especially important to secure high yields and product quality in highvalue crops.

\subsection{Livestock production}

A study by van Wagenberg et al. (2017) compared different aspects of sustainability including productivity in conventional and organic livestock production systems. For dairy production, seven out of 11 studies showed that organic dairy cows produced $4.7-32 \%$ less milk than conventional cows, while three studies did not find a significant difference. Reasons for this yield gap include a longer pasture season, less use of high-yielding breeds and lower levels of concentrate in diets. For beef cattle and laying hens, there are not enough studies available to draw general conclusions on yield differences in these sectors. Regarding broiler chickens in organic production, the use of slower growing breeds compared to the fast growing breeds used in conventional production results in lower yields in term of growth and feed conversion. The high incidences of mortality due to lameness and circulatory problems reported for birds of fast-growing breeds reared in organic production systems with long rearing periods further reduce the net yield (e.g. Wallenbeck et al. 2017; Rezaei et al. 2017). For pigs, productivity is mostly lower in organic production, with higher intake of feed in organic sows and a lower number or weaned piglets per sow. 
In Northern Europe, it is common practice to use the same high-yielding breeds in organic production as in conventional animal production. Hence, the genetic yield potential is the same in both systems. However, these breeds are developed in conventional production environments, so the genetic potential may not be realised to the same extent when environmental factors such as diet composition, housing or disease pressure change. For example, due to less intensive feeding strategies, including large forage allowances and pasture grazing, yields in organic ruminant production are generally lower than in conventional production. In many cases, the most high yielding breeds in conventional environments are also the most high yielding breeds in organic environments. In cases where genotype by environment interactions exist, e.g. indications of such interactions for fertility traits have been reported in studies comparing organic and conventional dairy production in Sweden, (Ahlman et al. 2011; Sundberg et al. 2010), the difference between various production environments may be lower. If existing genotype by environment interactions are not taken into account in the choice of breeds it can have severe effects on the yield in organic animal production (Wallenbeck 2009; Ahlman 2010). However, for dairy farming in Sweden, organic yields are only slightly lower than conventional (9321 compared with 10,222 kg energycorrected milk (ECM) per cow and year) due to similarities in the systems, e.g. high forage ratios in both (VS 2017). Organic and conventional beef production systems show similar results in terms of yield, for the same reason.

In Swedish pig production, slaughter weights are 1-5\% lower in organic production, but feed consumption is also higher (Wallenbeck 2012). Reports (although scarce) show increased piglet mortality and decreased sow productivity per year in organic herds compared with conventional herds (Wallenbeck et al. 2009). Organic hens (and other free range hens) are usually less efficient in terms of feed conversion ratio (minus 2-20\%) compared with laying hens housed in aviaries or in cages and commonly show increased mortality due to injury and disease. In organic broiler systems, net yield is also significantly decreased, for similar reasons (Rezaei et al. 2017). For pigs and poultry, the ban on synthetic amino acids in organic systems reduces the yield potential of the conventional hybrids (Eriksson et al. 2010b).

Animal health is a key factor influencing the net yield of any livestock production system. In some regards, organic livestock systems perform better than conventional systems, e.g. respiratory diseases are usually lower in organic herds (Hansson et al. 2000). In other areas, problems are more severe in current organic systems. For example, in poultry production morbidity due to parasite infections (i.e. coccidia and nematodes) is a problem, as organic regulations restrict the use of prophylactic medication, which is common in conventional production (Thapa et al. 2015). In pig production, there is an elevated risk of joint lesions in free-range pigs (Etterlin et al. 2014).

The therapeutic medications used in organic farming are identical to those used in conventional farming regarding antibiotics and anthelmintics, but the extended withdrawal times required in the organic regulations makes their usage less likely. In some countries, alternative medications (homoeopathic therapy or phytotherapeutic) are used. However, homoeopathy and phototherapy are not widely used in Sweden, as veterinarians are only permitted to prescribe therapeutic methods that are evidence-based.

Strategies to increase yield in organic livestock production that are common to all species include improved management, especially the use of optimal livestock diets, decreased mortality rates due to injury and disease and improved breeding that matches the requirements of organic production and the production environments for the animals in organic herds. Table 2 summarises species-specific strategies based on van Wagenberg et al. (2017).

\section{Risks and opportunities associated with increasing yields in organic production}

\subsection{Biodiversity}

The expansion of agricultural land, the decline in landscape heterogeneity, increased use of fertilisers and pesticides and conversion to systems with reduced crop diversity have had major effects on global biodiversity (Emmerson et al. 2016). Organic farming generally increases crop and landscape heterogeneity compared with conventional farming, which enhances biodiversity. For example, overall species richness on organic farms is on average 34\% (95\% CI: $26-43 \%$ ) higher than on conventional farms, according to one meta-analysis (Tuck et al. 2014). However, the magnitude of the positive effects varies widely among organism groups, e.g. for pollinators and predators species richness is $50 \%$ (95\% CI 27 $77 \%$ ) and $12 \%$ (95\% CI 1-24\%) higher, respectively, on organic farms (Tuck et al. 2014). The positive effects also show large variation across landscapes, e.g. with lower effects in more diverse landscapes (Winqvist et al. 2012). However, the benefits of organic production for biodiversity have been shown to be greatest at field level in some cases, while gains at farm or landscape level may be smaller (Rundlöf et al. 2010; Schneider et al. 2014).

Some practices for increasing yields in organic crop production carry a risk of attenuating the current positive effects on biodiversity. For example, higher frequency of mechanical weeding affects floral abundance in fields (Fig. 2), and may potentially decrease the density and species richness of organisms at higher trophic levels, such as arthropod generalist predators (Diehl et al. 2012). However, restoration or 
Table 2 Strategies to increase yields in organic livestock production that are applicable to Northern Europe. Based on van Wagenberg et al. (2017)

\begin{tabular}{|c|c|}
\hline Animal species & Strategies to increase yields \\
\hline $\begin{array}{l}\text { Dairy and beef } \\
\text { cattle }\end{array}$ & $\begin{array}{l}\text { - Use breeds/cows with high genetic capacity for milk production/growth } \\
\text { - Use feeds with high nutrient concentration (but adapted for each animal category) and } \\
\text { quality, e.g. high protein quality } \\
\text { - Improve feeding precision, e.g. diets targeting individual requirements and improved } \\
\text { feeding techniques } \\
\text { - Decrease calf mortality through e.g. breeding for easy calving } \\
\text { - Keep cattle healthy, e.g. by use of preventative healthcare such as methods for reducing } \\
\text { parasitic infestation } \\
\text { - For dairy, use milking routines that increase milk yield }\end{array}$ \\
\hline Pigs & $\begin{array}{l}\text { - Decrease piglet mortality through breeding and improved management and housing of } \\
\text { sows and piglets at farrowing and during the early nursing period } \\
\text { - Increase number of piglets per sow and year through mating during lactation } \\
\text { - Select suitable breeds and boars within breed } \\
\text { - Improve protein quality in feed through development of improved and/or new protein feed } \\
\text { sources } \\
\text { - Improve feeding precision, e.g. diets targeting individual requirements and improved } \\
\text { feeding techniques }\end{array}$ \\
\hline Broilers & $\begin{array}{l}\text { - Select breeds that are better adapted to long rearing periods and that have a moderate } \\
\text { growth rate }(<45 \mathrm{~g} \text { per day), aiming to decrease leg problems and circulatory diseases } \\
\text { - Optimise feeding, e.g. improve protein quality in feed, roughage with nutritional value } \\
\text { - Improve gut health, i.e. reduce parasite infections, decrease risk of campylobacter infection }\end{array}$ \\
\hline Laying hens & $\begin{array}{l}\text { - Decrease risk of pecking injuries through appropriate rearing, feeding and housing, } \\
\text { including environmental enrichment } \\
\text { - Create housing environments that are adapted to seasonal changes, i.e. reduce the risk of } \\
\text { impaired air quality and inappropriate ambient temperature } \\
\text { - Optimise outdoor facilities, e.g. improve housing design and the attractiveness of outdoor } \\
\text { runs and prevent accumulation of parasites and nutrients } \\
\text { - Improve protein quality in feed }\end{array}$ \\
\hline
\end{tabular}

conservation of refuge areas in field margins and habitats adjacent to arable fields may counteract negative effects on diversity at farm level and increase yields through provisioning of habitats for a number of organisms important for biological control (Benton et al. 2003; Rundlöf et al. 2010). Habitat manipulations aim to increase biodiversity locally or regionally by providing shelter and/or feed for natural enemies and pollinators, which otherwise have little chance of survival in
Fig. 2 Mechanical weeding (a) is effective for removing weeds, but negatively affects floral abundance in fields (b), which may also decrease the density and species richness of other organisms a

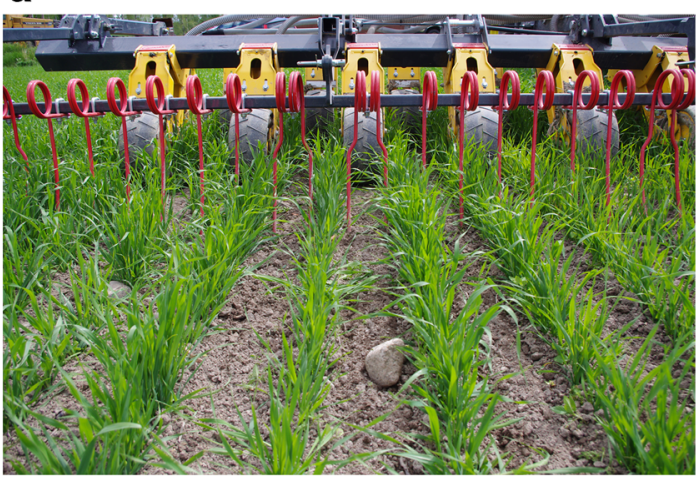

b

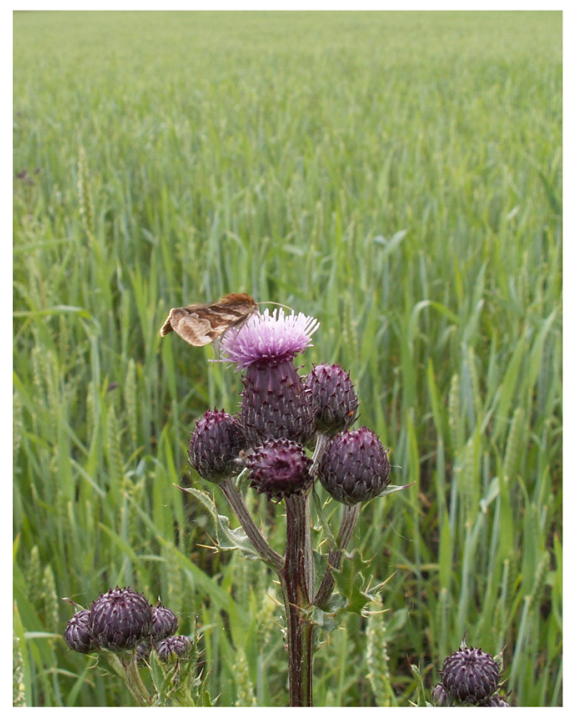


less complex landscapes and low-diversity agro-ecosystems (Gurr et al. 2017). Evidence is mounting that habitat manipulation approaches, e.g. flower strips, can be effective when applied at realistic scales (Tschumi et al. 2016; Gurr et al. 2016), and practical implementation of such techniques is slowly increasing around the world (Gurr et al. 2017). However, more research is needed on the design of diversity-promoting elements on farms and in the agricultural landscape. Ideally, these should not reduce productive areas, which will be particularly challenging in landscapes dominated by arable fields. More precise guidelines and specific standards for biodiversity conservation would be beneficial in organic regulations, but they must allow flexibility in relation to site-specific conditions.

Greater inputs of nutrients aimed at increasing organic yields and giving denser crops may also negatively affect diversity (Flohre et al. 2011; Gabriel et al. 2013). However, if inputs are applied with greater precision, this is likely to enhance yields and reduce nutrient losses and runoff, which will be positive for biodiversity due to reduced eutrophication of surrounding ecosystems (Cunningham et al. 2013).

Increased use of chemical crop protection agents approved for organic production, which promote high yield levels and yield stability, may concurrently have negative effects on a range of organisms in the field and the agricultural landscape. Nine chemical pesticide substances are currently approved for use in organic agriculture in Sweden and some of these have known negative effects on non-target organisms. Most notably, the use of pyrethrins, a plant extract approved as an insecticide in organic agriculture, poses risks for aquatic invertebrates. On the other hand, so-called 'basic substances' ${ }^{1}$ (Marchand 2015) are generally of low concern for biodiversity.

Other direct crop protection methods include augmentative biological control based on the release of microorganisms (Glare et al. 2012; Lacey et al. 2015) and macroorganisms (van Lenteren 2012) (e.g. antagonistic fungi or parasitoid wasps). Their increased use is likely to be accompanied by no or small negative effects on biodiversity. While the literature reports great potential for such control methods, their actual use is still limited, except in high-value crops (van Lenteren 2012).

Organic farmers today largely rely on plant varieties bred for high-input conventional systems. Future breeding for both increased yields and genetic diversity includes better adapted and genetically diversified crops for organic farming. This can

\footnotetext{
${ }^{1}$ Basic substances are a group of compounds of low concern that are not primarily designed as plant protection products, but may nonetheless be useful in plant protection. Basic substances have generally been used for a long time in other areas, with exposures to humans and environment. Of the current 15 EU-approved basic substances, 10 meet the definition of 'foodstuff' and are of animal or plant origin, e.g. whey and Urtica spp. extracts, and are therefore approved in organic agriculture (EC 2008).
}

increase yields through incorporation of multiple traits such as weed competitive ability, disease resistance and high nutrient uptake efficiency (Lammerts van Bueren et al. 2011). Furthermore, varieties selected under organic or low-input conditions have been shown to perform better in variety testing in organic environments, even if this is not always the case (Mikó et al. 2017). A selection made under stress may result in more competitive lines adapted to, e.g. lower levels of available nutrients, which is often the case in organic systems (Kirk et al. 2012). Although better plant varieties can bring multiple advantages, breeding strategies aimed at reducing weeds risk reducing in-field diversity just like other measures e.g. mechanical weeding.

More varied crop rotations, intercropping, e.g. combining grain legumes and cereals (Jensen et al. 2015), cover crops and variety mixtures (Sapoukhina et al. 2013) may disrupt the life cycle of certain pests or control their population, while increasing yields and biodiversity in agricultural fields and landscape diversity.

In Europe, the abandonment, rather than the expansion, of agricultural land poses a serious threat to many endangered species that have adapted to landscapes shaped by traditional low-intensity farming practices (Queiroz et al. 2014). Grazing and traditional methods of forage harvesting of semi-natural pastures are therefore important strategies for preserving a varied agricultural landscape with high biological and cultural values in many countries in Northern Europe (Luoto et al. 2003; Kalamees et al. 2012). The use of higher proportions of concentrate feeds in beef and dairy diets decreases time spent grazing, with associated negative consequences for pasture maintenance and for resource efficiency in terms of roughage conversion (i.e. $\mathrm{kg}$ milk or meat per kg roughage) (Weibull and Östman 2003). In addition, beef breed bulls may be preferred over steers (castrated male offspring) when aiming at increasing yields, due to bulls' greater potential for more rapid growth. However, bulls normally only graze during their first summer in Sweden due to safety of workers and the general public and for economic reasons, whereas steers normally graze for two or three summers (Hessle and Kumm 2011). Developing multifunctional and mixed animal production systems by, e.g. combining high-yielding dairy cows with breeds suitable for grazing, or using dual-purpose breeds, could also contribute to conserving biodiversity. More effective agri-environmental schemes that steer production in this direction need to be developed and also implemented in organic regulations.

\subsection{Emissions of greenhouse gases}

The climate impact from agriculture in Northern Europe arises mainly from emissions of nitrous oxide $\left(\mathrm{N}_{2} \mathrm{O}\right)$ from soils, driven largely by $\mathrm{N}$ application (44\% of GHG emissions from Swedish agriculture), carbon dioxide $\left(\mathrm{CO}_{2}\right)$ emissions from 
organic soils (12\%), methane $\left(\mathrm{CH}_{4}\right)$ from enteric fermentation in ruminants $(26 \%)$ and emissions of $\mathrm{N}_{2} \mathrm{O}$ and $\mathrm{CH}_{4}$ from manure management (5\%) (SBA et al. 2012). Fossil energy use in field machinery and animal housing add to these emissions, but to a lesser extent (10\% of GHG emissions). In conventional agriculture, the production of mineral fertilisers is also a considerable source of GHG. Although organic farming does not use energy-demanding mineral fertilisers, the production and transport of some organically acceptable fertilisers require non-negligible amounts of fossil energy input, while GHG emissions can also arise during storage (Spångberg 2014).

The yield level is influential when calculating the climate impact per unit product, as the GHG emissions from soils and inputs are distributed over the total output (Röös et al. 2011). Therefore, organic products are frequently assessed as having similar or larger climate impacts per unit product than conventional products, as the lower GHG emissions from avoidance of mineral fertilisers and other inputs are cancelled out by the lower yields (Clark and Tilman 2017). For $\mathrm{N}_{2} \mathrm{O}$ emissions specifically, Skinner et al. (2014) showed that for yield gaps larger than $17 \%, \mathrm{~N}_{2} \mathrm{O}$ emissions are higher for organic products than for conventional products. Hence, there is an opportunity to combine increased yield in organic agriculture with reduced climate impact if yield increases can be achieved with no or low increases in GHG emissions from fields and inputs.

However, measures taken to increase yields in organic agriculture have complex effects on the climate impacts of production. As described below, there are ways to increase yields that have clear co-benefits for reducing the climate impacts. However, the climate effects of increased yield are often not so clear-cut and the overall balance between increasing and decreasing GHG emissions depends on local conditions and can only be determined on a case-by-case basis.

Management practices aimed at achieving higher yields by increasing plant nutrient availability, e.g. by reducing $\mathrm{N}$ leaching losses using catch crops or manure spreading techniques for reduced ammonia $\left(\mathrm{NH}_{3}\right)$ emissions, are all beneficial for reducing $\mathrm{N}_{2} \mathrm{O}$ emissions from soils. Cropping systems and management practices that sequester carbon in soils and standing biomass, e.g. through the use of catch crops (Poeplau and Don 2015), biochar (Kammann et al. 2017) or agroforestry (Fagerholm et al. 2016), can also reduce the climate impacts, while promoting soil fertility and increased crop yields.

Increased used of mechanical weeding increases $\mathrm{CO}_{2}$ emissions as a result of fossil fuel combustion. However, the climate impact from farm machinery use is usually a minor part of the climate impact of production (Röös et al. 2011), so the increase in yield from weed control can often compensate climate-wise for the increased fossil fuel use. Apart from reducing GHG losses from organic agriculture, increased use of renewable resources in organic agriculture is in line with organic principles. Biogas production from agricultural residues and/or manure is beneficial from a climate perspective, as it provides renewable energy (Kimming et al. 2015; Siegmeier et al. 2015). Yields can also increase, as the anaerobic digestion process increases the plant availability of $\mathrm{N}$ in digestate used as fertiliser. In the future, there will be new opportunities for increasing yields through more intensive machine use without increasing GHG emissions, by a transition to electric machinery in combination with renewable electricity.

Livestock diets with a higher proportion of concentrate feed increase milk yields and growth rates, and thus reduce methane emissions per unit product. However, emissions from feed production, including soil carbon sequestration or losses, influence the total climate impact of production. Sequestration is generally larger in ley cultivation than for annual crops (Poeplau et al. 2015). Production of a ruminant diet with a large proportion of forage can therefore lead to greater sequestration (or lower losses) of carbon in soils than a diet based on more grains and concentrates.

The joint production system of dairy, which produces both milk and meat, constitutes an important exception to the rule of thumb that increased yields reduce the climate impact. When milk yields increase, the amount of meat from the dairy system decreases, as fewer cows are needed and hence fewer calves are born. If this 'lost' meat is replaced by beef meat from suckler herds, the total climate impact from milk and meat production increases, as the climate impact of beef from suckler herds is higher than that from dairy. Hence, the total climate impact from milk and meat production can be lower with lower-yielding dairy cows (Flysjö et al. 2012).

In summary, there are many examples of how increasing yields can lead to decreased climate impact, but the examples from ruminant production illustrate how important it is to consider the climate impact from agricultural products from a systems perspective on a case-by-case basis, to avoid suboptimisation. Moreover, estimation of climate impacts is hampered by the large variability in biological systems, including the large uncertainties in measuring or modelling $\mathrm{N}_{2} \mathrm{O}$ emission rates and soil carbon dynamics (Nylinder et al. 2011; Powlson et al. 2011).

\subsection{Nutrient losses}

Loss of $\mathrm{N}$ and phosphorus (P) from agricultural systems to waterways is a serious problem causing eutrophication, particularly in coastal areas. Agriculture is also the main contributor to airborne $\mathrm{NH}_{3}$ emissions, mainly from manure management (SBA et al. 2012).

Increased inputs of nutrients, especially $\mathrm{N}$, have great potential to increase yields in organic farming (Doltra et al. 2011). However, there is an increased risk of nutrient losses with higher $\mathrm{N}$ inputs that needs careful consideration. The risk is greatest when $\mathrm{N}$ released from organic fertilisers does not match crop uptake or when $\mathrm{N}$ fertilisation rates start to 
approach or exceed the 'economic optimum level', calculated from known yield response to $\mathrm{N}$ mineral fertilisation (Delin and Stenberg 2014). Above the optimum, the yield response ceases and $\mathrm{N}$ leaching losses increase exponentially (Fig. 3). Currently, $\mathrm{N}$ inputs in organic crop production are often well below the optimum level (SS 2017). Simulations show potential to increase yields through additional use of manure or other organic fertiliser inputs, without negative effects on $\mathrm{N}$ leaching (Doltra et al. 2011). Careful management of animal manure to minimise $\mathrm{NH}_{3}$ losses is also crucial, including the use of covers on manure storage facilities and precision spreading. Bandspreading in growing crops and direct incorporation of manure in soils minimises $\mathrm{NH}_{3}$ emissions, increases $\mathrm{N}$ use efficiency and raises yield levels (Webb et al. 2013).

One of the main sources of $\mathrm{N}$ in organic systems is biological $\mathrm{N}$ fixation by annual and perennial legumes. The risk of $\mathrm{N}$ losses may increase with a large proportion of legumes in the crop rotation, as it is challenging to synchronise timing of $\mathrm{N}$ release with crop requirements (Olesen et al. 2009). For example, incorporation of N-rich crop residues in autumn before, e.g. sowing of winter cereals increases the risk of leaching, due to high $\mathrm{N}$ mineralisation in autumn often exceeding crop $\mathrm{N}$ uptake (Torstensson et al. 2006). Appropriate management practices may reduce such risks. Askegaard et al. (2011), Doltra et al. (2011) and Plaza-Bonilla et al. (2015) found potential for catch crops, i.e. crops grown between main crops with the purpose of taking up residual available nutrients, mainly $\mathrm{N}$, in soil, to reduce $\mathrm{N}$ losses and release $\mathrm{N}$ to the main following crop. In Nordic long-term field trials at different sites, catch crops have improved mean grain yields, corresponding to $0.2-2.4 \mathrm{Mg} \mathrm{DM} \mathrm{ha}^{-1}$ for spring oats and $0.1-1.5 \mathrm{Mg} \mathrm{DM} \mathrm{ha}{ }^{-1}$ for spring barley (Doltra and Olesen 2013). Spring tillage on suitable soils is another efficient strategy to decrease $\mathrm{N}$ leaching losses during the winter season (SMED 2015). However, on clay soils, in combination with cold conditions early in the growing season, such a measure could reduce $\mathrm{N}$ mineralisation rates, negatively affecting crop $\mathrm{N}$ availability in spring and early summer and leading to lower yield. Using genetically diverse crops, including intercrops and variety mixtures, that have the potential to perform well under different environmental conditions also minimises the amount of residual available nutrients in the soil (Wolfe et al. 2008).

Some nutrient losses are however inevitable. Therefore, using vegetation zones, wetlands, sedimentation ponds and other measures in the landscape to protect vulnerable waters through capturing lost N and P is crucial. Such strategies need to be incorporated into organic regulations to prevent eutrophication from organic agriculture, especially if nutrient inputs are increased.

The availability of $\mathrm{N}$ and other nutrients in forms approved for organic production is already limited. Due to the inevitable losses, both increased recycling of nutrients from society and 'new' nutrients will be needed for organic yields to increase and organic agriculture to expand. If organic regulations are modified to allow general use of biogas digestate from e.g. food and slaughter waste and/or human urine, which has high levels of plant-available $\mathrm{N}$, this gives opportunities for increased recycling and more precise timing of $\mathrm{N}$ fertilisation. This in turn can improve $\mathrm{N}$ use efficiency and yield levels and potentially reduce $\mathrm{N}$ losses (Salomon and Wivstad 2013). Some suggest that restricted use of mineral $\mathrm{N}$ fertilisers produced by renewable energy (Tallaksen et al. 2015) may be an interesting option to consider as a way of providing 'new nitrogen' that could be supplied with high precision. This is currently far from being allowed in organic regulations and challenges the basic principle that organic farming relies on, i.e. feeding the soil rather than the plant. It also feeds a model of organic farming which is about input substitution rather than system redesign. A potentially less controversial option may be source separation of human wastes, such that diluted urine could be used in a precision $\mathrm{N}$ fertiliser context. There are currently proposals to allow $\mathrm{P}$ fertilisers such as struvite which are derived from human waste (EC 2016). If organic yields are to increase and organic agriculture to expand substantially novel approaches to nutrient supply are unavoidable.

Increased use of concentrate feeds in organic livestock production to increase yields risks leading to increased amounts
Fig. 3 Increasing nitrogen fertiliser rates and effect on a spring oats yield response and $\mathbf{b}$ nitrogen leaching losses (data from Delin and Stenberg 2014) a

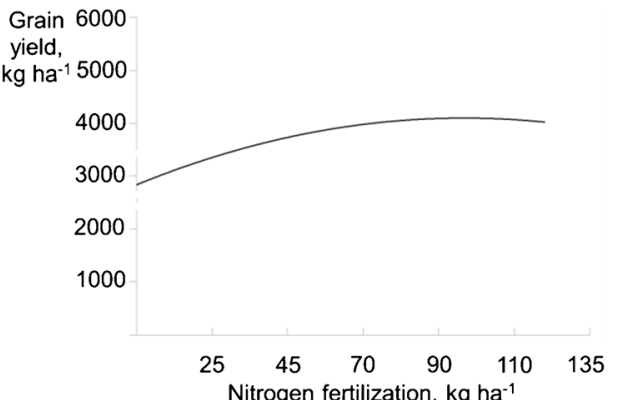

b

Nitrogen 60 leaching, kg N ha-1 50

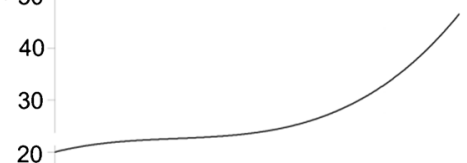

10

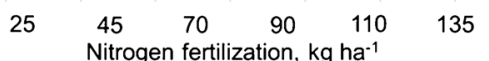


of nutrients in the manure and an increased risk of subsequent nutrient losses, especially of $\mathrm{NH}_{3}$ (Oenema et al. 2007). Due to the ban on synthetic amino acids in organic production, pigs and poultry are often overfed with protein $(+5-10 \%$ of crude protein in laying hens) in order to reach sufficient levels of certain amino acids in the feed (van Krimpen et al. 2016). This may lead to increased $\mathrm{N}$ losses to the environment, but the impact varies substantially from farm to farm (Degre et al. 2007). The need to overfeed pigs and poultry could be reduced by the introduction of novel protein feeds such as mussel meal (Jönsson et al. 2011) and insects (Khusro et al. 2012) and/or removal of the ban on synthetic amino acids in future organic regulations.

Re-coupling of animal production and production of feed (Garnier et al. 2016), accompanied by development of new business models and partnerships between organic farmers (Asai and Langer 2014), has been proposed as an option to reduce $\mathrm{N}$ losses. Such integration could increase yield levels in organic arable crop production due to greater access to nutrients (Doltra et al. 2011). Crop-livestock integration with ruminants also introduces leys on arable farms, promoting crop yields through increased soil fertility and reducing the risk of $\mathrm{N}$ and $\mathrm{P}$ losses (Aronsson et al. 2007).

\subsection{Soil fertility}

Agricultural soils are affected by many anthropogenic pressures, such as loss of soil organic carbon (SOC), nutrient depletion, soil compaction and heavy metal deposition (Smith et al. 2016). In Northern Europe, however, the situation is not as severe as in some other parts of the world. In Sweden, cropland topsoils have an average organic matter content of $4 \%$ (albeit with high variation), which is considered sufficient to maintain soil fertility for crop production (Eriksson et al. 2010a). A high SOC level is a key characteristic of soil fertility, as it promotes soil structure, aeration, water-holding capacity, chemical buffering capacity, soil microbial activity, plant root development and continuous release of plant nutrients through mineralisation. According to a global review by Gattinger et al. (2012), the results indicated that soils in organic cropping systems have significantly higher levels of SOC than those in conventional systems. Tentative explanations include increased external carbon inputs, organic matter recycling and extended crop rotations with forage legumes in organic systems.

Increased yields lead to increased amounts of crop residues being incorporated into soils, raising SOC levels (Diacono and Montemurro 2010). Increasing fertiliser inputs to increase yields reduces the risk of depletion of a range of essential soil nutrients. This is particularly important in organic stockless systems and in systems with small or no external inputs of fertilisers (Watson et al. 2002). Increased use of fertilisers with high nutrient availability, e.g. biogas digestate, or future introduction of renewable mineral fertilisers in organic farming could provide the potential to increase yields through increased precision in fertiliser application. However, such fertilisers may not contribute to SOC building to the same extent as fertilisers rich in organic carbon.

Practices typical of 'conservation agriculture', including diversified crop rotations, maximum soil cover and reduced tillage, contribute to reduced soil degradation (Cooper et al. 2016). However, implementation of reduced tillage is limited in organic agriculture, mainly because of the important role of tillage for control of weeds. Shallow inversion tillage at strategic stages in the crop rotation could be a good compromise to ensure both effective weed control and SOC gains (Cooper et al. 2016).

A concern for soil fertility associated with spreading of liquid fertilisers, as well as mechanical weeding, is the risk of soil compaction. The development of lighter machinery for mechanical weeding (e.g. self-driving weeding robots), fertiliser spreading through pipelines and processes for reducing the water content in liquid fertilisers will help to reduce this problem.

As discussed in Section 3.3, nutrient recycling within the food system needs to be improved to maintain long-term sustainable nutrient supply and there are several promising options (Oelofse et al. 2013). However, urban waste products may contain a number of contaminants, including heavy metals, e.g. Cd, which is of great concern for public health (Åkesson et al. 2014). New techniques are needed for safe recycling systems, e.g. by source separation of sewage (Spångberg 2014). There are also various technologies to recover $\mathrm{P}$ from wastewater and sewage sludge by crystallisation or precipitation, with reduced risk of contamination compared with untreated sewage sludge. Treated sewage sludge products may have higher quality concerning contaminants than fertilisers approved in current organic regulations, such as natural phosphate rocks or even animal manures (Wollman and Möller 2015). Closing the nutrient loop is one of the major sustainability challenges for agriculture going forward. However, as current organic regulations hinder the use of many urban waste products, organic agriculture is actually less progressive in this area than conventional agriculture.

As described in Section 3.2, higher proportions of concentrates in livestock diets to increase livestock yields require more annual cropping, which risks less SOC formation compared with leys (Freibauer et al. 2004). The importance of including clover/grass ley in the crop rotation for preserving carbon stocks in soils is demonstrated in Swedish monitoring datasets by higher organic matter content in soils on dairy farms than on pig farms which mainly grow annual crops (Eriksson et al. 2010a). Consequently, in order to increase yields in production systems with ruminants, increased forage quality through, e.g. optimising ley harvesting times (Nadeau 
et al. 2015) would be more favourable for promoting soil fertility than introducing higher concentrate proportions.

\subsection{Animal health and welfare}

There have been enormous increases in livestock productivity in recent decades. In Northern Europe, yields in pig production and milk yield per dairy cow have approximately doubled since the 1960s. The division of the domestic hen into egglaying breeds and meat-producing broiler breeds has increased poultry productivity dramatically (Appleby et al. 2004). However, modern industrialised livestock production systems affect the health and welfare of farm animals in many ways, including health problems related to breeding for high productivity (e.g. leg problems in broilers, high piglet mortality in pork production due to smaller and less vital piglets and mastitis in dairy cows) and limitations on animals expressing their natural behaviour due to being reared in confined and barren environments (e.g. restriction of movement due to crating of sows and the development of injurious behaviours such as tail biting in pork production and feather pecking in poultry) (von Keyserlingk and Hotzel 2015).

Continued breeding for high growth rates, without taking other important breeding traits such as animal health and behaviour into account, and the use of these breeds in organic production risk aggravating current health problems further. For example, there is little or no difference in cow health between organic and conventional dairy systems in Sweden (Fall et al. 2008; Sundberg et al. 2009) due to the small differences in production system, i.e. same breeds and similar yield levels. Hence, Nordic organic dairy systems are among the most high-yielding dairy systems globally, but this comes at a price. Dairy cows commonly suffer from udder health disturbances and locomotion disorders; in 2013/2014, 26\% of Swedish dairy cows were treated for some medical condition, although breeding in Sweden combines production, health, fertility and longevity traits into a 'total merit index' (Oltenacu and Broom 2010; Rodriguez-Martinez et al. 2008). Joint lesions arise in all pig production systems, but they are more frequent and severe in organic compared with conventional production due to higher stress on pig joints in spacious and outdoor environments, as the leg conformation of modern, fast-growing pigs is not suited to the level of exercise required with large space allowances (Engelsen Etterlin et al. 2015). Hence, it is worth discussing whether still higher yields per animal are desirable and in line with organic principles; attention should perhaps focus on improving animal health and welfare at current production levels or even accepting lower yield per animal if necessary. The development of more suitable breeds should be considered, possibly using or crossbreeding with smaller or indigenous breeds possessing traits favourable for animal health and behaviour in the local environment.
However, there are short-term solutions that can be implemented in current organic livestock systems in Northern Europe to improve welfare and increase yields and there are several examples of clear synergies in this area. One example is the use of more suitable breeds that are available internationally today. The use of slower-growing breeds in broiler production could improve animal health and also increase net yield at flock level, due to more appropriate behaviour leading to an increased number of broilers being healthy at slaughter compared with fast-growing breeds (Rezaei et al. 2017; Wallenbeck et al. 2017).

The implementation of management practices that lead to healthy animals with high fertility and without behavioural disturbances would also contribute to higher yields at herd level and naturally improved animal welfare. For dairy systems, such practices include increased milking frequency, extended calving interval (Österman 2003) and the use of methods for reducing parasite infestation (Höglund et al. 2013). For pigs, pasture and roughage allowances allow natural foraging behaviour and decrease aggressive interactions between pigs (Høøk Presto 2008), although pigs kept on pasture are more susceptible to diseases caused by parasites (VKM 2014). Designing sow and piglet housing to allow sows and piglets to communicate and behave in an optimal way, and herdsmen to care for weak piglets, is essential for reducing piglet mortality and thus improving yields at herd level. Selection of sows with suitable maternal abilities in terms of milk production and maternal behaviour is another key factor (Wallenbeck et al. 2009). Hygiene measures in houses and rotation of outdoor areas are important for all livestock species. Such measures have proven effective for, e.g. organic poultry by the low prevalence of salmonella (Wierup et al. 2017).

Improved and well-balanced livestock diets to raise yields can also improve animal welfare by e.g. preventing injurious behaviour and avoiding nutrient deficiencies. For example, problems with feather or vent pecking in laying hens can be reduced by feeding an optimal diet with e.g. high-quality protein and roughage allowances (Rodenburg et al. 2013). If future organic regulations were to allow supplementation of essential amino acids in livestock diets, that would be a major advantage, allowing avoidance of over-feeding (Eriksson et al. 2010b; Leenstra et al. 2014). Improved utilisation of the protein available in roughages is another route, which would improve pig welfare through enabling foraging behaviour, reduce injurious behaviour and thereby potentially decrease the risk of disease (Presto et al. 2013; Wallenbeck et al. 2014).

Ruminants are adapted to a forage-based, fibre-rich diet and feeding high levels of concentrate may lead to metabolic diseases (Jorgensen et al. 2007). However, as organic regulations mandate high levels of forage in ruminant diets, the risk of such problems in strategies to increase yields involving higher concentrate proportions in organic ruminant diets is 
small. Improved forage quality makes it possible to use high proportions of forage (e.g. 60-70\% of total dietary dry matter) even for high-yielding cattle (Patel 2012; Nadeau et al. 2015; Johansson et al. 2016). Cows fed forage-based diets up to seven lactations showed no negative development in terms of production efficiency with age, older cows were even able to ingest more (Grandl et al. 2016). As cows in this case also lived longer, it could be argued that also welfare increased. Therefore, there is great potential to maintain or even increase milk yields and growth rates using forage-dominated diets that also improve cattle welfare. However, if time spent grazing decreases as a consequence of changed feeding regimes to increase yields, this will also negatively affect ruminant welfare; significant benefits for animal health, fertility and farmer profitability have been found for grazing systems compared with year-round indoor systems (Ekesbo 2015).

One way to achieve increased yields in beef production with few negative impacts on animal welfare is to use dairy/ beef cross-breed animals, which would allow dairy cows to produce calves with the good growth potential of the beef breeds. The cross-breed calves could be raised as heifers or steers in grazing systems, providing potential synergies for yields, biodiversity conservation (Section 3.1 ) and animal welfare.

\subsection{Human nutrition and health}

It is well known that the input levels of plant nutrients affect plant development and composition (Bindraban et al. 2015; Wiesler 2012), as well as crop yields. To some degree, yield and nutritional quality may be divergent breeding goals (Morris and Sands 2006), since historically, the breeding and production of high-yielding varieties has led to a decreasing content of certain minerals in some vegetable and cereal crops (Marles 2017).

The production system, organic or conventional, generally has no or only a small effect on the concentrations of most nutrients and secondary metabolites in crops. The exception to this is phenolic compounds, where various meta-analyses report an overall modestly higher concentration (14-26\%) of total phenolics in organic crops (Mie et al. 2017). Increased $\mathrm{N}$ fertilisation has a negative effect on the concentration of phenolic compounds in crops (Treutter 2010). Phenolic compounds from plant sources are believed to carry benefits for human health, although this is not fully understood (Del Rio et al. 2012). Based on current knowledge, it is not possible to derive any specific health benefit from the slightly higher concentration of phenolic compounds in organic crops. Accordingly, increasing yields in organic farming by increasing crop fertilisation is not expected to lead to nutritionally relevant effects on crop composition.

In a 2-year controlled field trial examining the composition of white cabbage using untargeted metabolomics, measuring approximately 1600 compounds, researchers were able to discriminate between cabbage from organic and conventional production, but not between cabbage from one low-input and one high-input organic system (Mie et al. 2014). Therefore, intensifying organic crop production within the range of current organic fertilisation practices is not expected to lead to major changes in plant composition.

The use of chemical pesticides is strongly restricted in organic production. Limited data indicate that toxicity-weighted human dietary pesticide exposure from organic foods in Sweden is far lower than exposure from conventional foods (Beckman 2015), and the associated health risks are small. However, 10 compounds with some type of identified human toxicity are currently approved in organic crop production in the EU (Mie et al. 2017), and increased inputs of these compounds, which are likely to lead to increased human exposure, are per se undesirable. Conversely, increased inputs in the form of 'basic substances' are regarded to be of low concern for human health (Marchand 2015). Likewise, the use of microorganisms, macroorganisms or habitat manipulation in plant protection is not associated with any known risks for humans.

Lowering the crop pest and disease burden by good management could in some cases result in lower concentrations of some plant defence compounds that are expressed in response to infestation. However, there is no convincing evidence that this effect is relevant for human nutrition. For cereal crops, deoxynivalenol (DON) is an important fusarium toxin and a common cause of cereal crop losses due to maximum limits for food being exceeded. DON exposure is close to or higher than the tolerable daily intake (TDI) for certain subpopulations in Europe (EFSA 2013). On average, organic cereals have lower DON levels than conventional cereals (SmithSpangler et al. 2012). Increasing yields through higher N fertilisation is likely to lead to increased DON concentration in cereal crops. On the other hand, increasing marketable yields by counteracting fusarium infestation, through management practices such as suitable crop rotation, incorporation of crop residues in soils, choice of cultivar and proper drying and storing of cereals after cropping, should lead to decreased DON concentration in the crop (Kabak et al. 2006).

In a recent review (Bedoussac et al. 2015), cereals in cereal-legume intercropping systems had a higher $(0.33 \mathrm{com}-$ pared with $0.27 \mathrm{~kg} \mathrm{~m}^{-2}$ ) and more stable grain yield than the mean of partner crops grown as sole crops under the same conditions. Cereal intercrops also had a higher protein content compared with sole crops (11.1 compared with $9.8 \%$ ), while the legume protein content was not affected by intercropping.

In animal feeds, most ingredients in concentrate feeds, such as cereals, contain less than $10 \%$ omega- 3 fatty acids of total fatty acids, while grass and red clover contain between 30 and $50 \%$ omega-3 fatty acids (Woods and Fearon 2009). Omega-3 fatty acids are a group of fatty acids that are essential to 
humans and, in general, increased human intake is desirable (Burdge and Calder 2006). The fatty acid composition in feed largely determines the fatty acid composition of milk or meat, although this relationship is not linear for ruminants (KhiaosaArd et al. 2015; Woods and Fearon 2009). Consequently, higher inputs in the form of concentrate feeds are likely to negatively affect the omega-3 fatty acid content of the product; on average, organic cow milk has $56 \%$ (95\% CI 38, 74\%) higher concentrations of omega-3 fatty acids (ŚrednickaTober et al. 2016b). A similar, plausible, although less welldocumented relationship appears to exist for meats (Średnicka-Tober et al. 2016a). The nutritional consequences are likely to be small, as studies from various European countries indicate that dairy products on average contribute 5-16\% and meat $12-17 \%$ of the total omega- 3 fatty acid intake in human diets (Mie et al. 2017), although this contribution may be higher for certain dietary patterns. A modest increase in concentrate feeds in organic animal production is therefore not expected to lead to a substantial decrease in omega-3 fatty acids in the human diet. Measures to improve animal health in general to avoid yield losses due to animal diseases could lead to lowered pathogen levels in e.g. poultry meat.

\subsection{Farm profitability}

The profitability in organic production varies considerably between products, regions and farms. However, many studies have concluded that organic farms are frequently more profitable than conventional farms due to higher price premiums, government support and/or lower costs (Nemes 2009). In a recent meta-analysis, Crowder and Reganold (2015) found that without price premiums organic farming would be significantly less profitable than conventional agriculture due to 10 $18 \%$ lower yields, showing the importance of price premiums for profitability in organic farming. For the farmer, the economic effect of increased yields in organic agriculture will depend on how the revenues of the farming business are affected, including how consumers respond to such changes and the costs associated with achieving increased yields.

The profitability of organic farming hence strongly depends on consumers being willing to pay a price premium. Crowder and Reganold (2015) found that a premium of 5-7\% is required in order for the profits in organic farming to equal to those in conventional farming, while the actual premium is around $30 \%$. Reasons for buying organic food include health and nutritional concerns, perceived superior taste, environmental and animal welfare concerns and distrust in conventional food production (Hoffmann and Wivstad 2015). Although higher yields per se do not necessarily affect demand, a change towards more intense practices in organic farming, making it more similar to conventional farming in some respects e.g. by increased use of fertilisers and concentrate feeds, may negatively affect the premium some consumers are willing to pay for organic food (Adams and Salois 2010). Furthermore, increased yields would presumably lead to a larger supply of organic products, which if not matched with a corresponding increase in consumer demand would result in a reduction in prices. In countries where organic production receives government support, another potential risk to farm revenues of increasing yields is that it may be used as an argument for removing subsidies.

Improving productivity generally requires investment in additional capital (e.g. machinery or additional land) and/or labour (e.g. increased mechanical weeding) which may increase the financial risk of the farmer. Hence, increased yields may not be preferred by all farmers, although some studies have found organic farmers to be less risk-averse than conventional farmers (Gardebroek 2006) and intensification may reduce the yield variation.

Variations in yield, and hence in economic returns, between organic farms have been partly explained by differences in management and marketing skills. Experience and knowledge influence farmer behaviour. For example, a flexible approach to crop rotations on organic farms in Sweden has been found to be positively correlated to the experience of the farmer (Chongtham et al. 2016). Knowledge transfer between farmers is important in improving management skills and the ability of farmers to apply best available management practices. Yield increases which depend on investments in costly specialist machinery (e.g. for mechanical weed control) may create incentives for more extensive cooperation in sharing machines. Adoption of new technologies is becoming easier and less costly as the technology becomes more widespread. Thus, more widespread uptake of good organic practices will promote yield increases (Läpple and van Rensburg 2011). This stresses the importance of effective communication channels for knowledge sharing and transfer in improving yields and productivity in organic farming.

\section{Summary and reflections}

Table 3 summarises the most likely areas of conflict and synergies associated with different ways of increasing yields in organic agriculture identified in this review.

This review shows that in most areas, there are both risks and opportunities associated with strategies to increase yields in organic production. However, increased $\mathrm{N}$ inputs have many risks and few opportunities for synergies, whereas for reduced losses only opportunities, and no risks, were identified (Table 3). The final outcome depends largely on management, i.e. how strategies to increase yields are implemented and whether trade-offs are accounted for and managed. Knowledge, skills and system thinking are crucial in this endeavour, as we demonstrate with numerous examples. The ambition of organic farming 
Table 3 Risks and opportunities in different areas associated with different strategies to increase yields in organic production

Strategies to increase yields

\begin{tabular}{|c|c|c|c|c|c|c|}
\hline $\begin{array}{l}\text { Affected } \\
\text { issue }\end{array}$ & $\begin{array}{l}\text { Increased } \mathrm{N} \text { input in } \\
\text { cropping }\end{array}$ & $\begin{array}{l}\text { More intense } \\
\text { weed control }\end{array}$ & $\begin{array}{l}\text { Increased disease and } \\
\text { pest control }\end{array}$ & $\begin{array}{l}\text { Breeding for higher } \\
\text { yields } \\
\text { (animals and crops) }\end{array}$ & $\begin{array}{l}\text { More concentrates in } \\
\text { ruminant diets }\end{array}$ & $\begin{array}{l}\text { Reduced losses } \\
\text { (animals and } \\
\text { crops) }\end{array}$ \\
\hline Biodiversity & $\begin{array}{l}\text { Risk of reduced floral and } \\
\text { faunal diversity }\end{array}$ & $\begin{array}{l}\text { Risk of reduced } \\
\quad \text { biological } \\
\text { control caused } \\
\text { by reduced } \\
\text { floral } \\
\text { abundance } \\
\text { negatively } \\
\text { affecting } \\
\text { generalist } \\
\text { predators }\end{array}$ & $\begin{array}{l}\text { Risk of increased use of } \\
\text { substances, with } \\
\text { negative effects on } \\
\text { non-target } \\
\text { organisms. } \\
\text { Opportunity for } \\
\text { biological control } \\
\text { and new control } \\
\text { products }\end{array}$ & $\begin{array}{l}\text { Risk of lowered } \\
\text { genetic diversity } \\
\text { in high-yielding } \\
\text { varieties. } \\
\text { Opportunity for } \\
\text { dual breeds and } \\
\text { breeding for high } \\
\text { pasture utilisation }\end{array}$ & $\begin{array}{l}\text { Risk of reduced utilisation } \\
\text { of semi-natural pastures } \\
\text { and associated species } \\
\text { loss }\end{array}$ & $\begin{array}{l}\text { Opportunity for } \\
\text { land sparing } \\
\text { giving room for } \\
\text { elements } \\
\text { improving } \\
\text { diversity }\end{array}$ \\
\hline $\begin{array}{l}\text { Emissions of } \\
\text { GHG }\end{array}$ & $\begin{array}{l}\text { Risk of increased nitrous } \\
\text { oxide emissions }\end{array}$ & $\begin{array}{l}\text { Risk of increased } \\
\text { emissions from } \\
\text { fossil fuels }\end{array}$ & $\begin{array}{l}\text { Opportunity for lower } \\
\text { climate impact due } \\
\text { to more efficient } \\
\text { production }\end{array}$ & $\begin{array}{l}\text { Opportunity for } \\
\text { lower climate } \\
\text { impact due to } \\
\text { more efficient } \\
\text { production }\end{array}$ & $\begin{array}{l}\text { Opportunity for lower } \\
\text { methane from ruminant } \\
\text { products due to faster } \\
\text { growth rates and higher } \\
\text { milk yield. Risk of } \\
\text { increased soil C loss or } \\
\text { less soil C sequestration } \\
\text { due to less ley } \\
\text { cultivation }\end{array}$ & $\begin{array}{l}\text { Opportunity for } \\
\text { lower climate } \\
\text { impact due to } \\
\text { more efficient } \\
\text { resource use }\end{array}$ \\
\hline $\begin{array}{r}\text { Nutrient } \\
\text { losses }\end{array}$ & $\begin{array}{l}\text { Risk of increased } \mathrm{N} \\
\text { leaching }\end{array}$ & $\begin{array}{l}\text { Risk of increased } \\
\text { N leaching. } \\
\text { Opportunity } \\
\text { for more } \\
\text { vigorous crop } \\
\text { growth with } \\
\text { reduced } \\
\text { leaching }\end{array}$ & $\begin{array}{l}\text { Opportunity for } \\
\text { reduced losses due to } \\
\text { higher production } \\
\text { stability over time }\end{array}$ & $\begin{array}{l}\text { Opportunity for } \\
\text { reduced } \mathrm{N} \text { losses } \\
\text { by more efficient } \\
\text { crop } \mathrm{N} \text { uptake, for } \\
\text { livestock breeds } \\
\text { by more efficient } \\
\text { feed } \mathrm{N} \text { utilisation }\end{array}$ & $\begin{array}{l}\text { Increased } \mathrm{N} \text { leaching risk } \\
\text { due to more annual } \\
\text { crops and less ley in } \\
\text { rotations, risk of farm P } \\
\text { surpluses due to import } \\
\text { of concentrates }\end{array}$ & $\begin{array}{l}\text { Opportunity for } \\
\text { reduced losses } \\
\text { due to more } \\
\text { efficient } \\
\text { resource use }\end{array}$ \\
\hline Soil fertility & $\begin{array}{l}\text { Opportunity for increased } \\
\text { SOC levels and soil } \\
\text { nutrient stocks through } \\
\text { more crop residues and } \\
\text { organic fertilisers. Risk } \\
\text { of contamina-tion by } \\
\text { toxic substances in } \\
\text { urban wastes }\end{array}$ & $\begin{array}{l}\text { Opportunity for } \\
\text { more crop } \\
\text { residues which } \\
\text { promote SOC } \\
\text { levels. } \\
\text { Risk of soil } \\
\text { compaction }\end{array}$ & $\begin{array}{l}\text { Opportunity for yield } \\
\text { increases, giving } \\
\text { more crop residues } \\
\text { promoting SOC } \\
\text { levels }\end{array}$ & $\begin{array}{l}\text { Risk or opportunity } \\
\text { depending on } \\
\text { amounts of crop } \\
\text { residues of new } \\
\text { varieties, } \\
\text { opportunity with } \\
\text { perennial cereals }\end{array}$ & $\begin{array}{l}\text { Risk of lower SOC levels } \\
\text { due to lower ley } \\
\text { proportion in crop } \\
\text { rotations }\end{array}$ & - \\
\hline $\begin{array}{l}\text { Animal health } \\
\text { and welfare }\end{array}$ & - & - & - & $\begin{array}{l}\text { Risk of less robust } \\
\text { animals with } \\
\text { potentially } \\
\text { increased health } \\
\text { problems }\end{array}$ & $\begin{array}{l}\text { Risk of metabolic disease } \\
\text { in cattle, risk of reduced } \\
\text { welfare due to less } \\
\text { grazing }\end{array}$ & $\begin{array}{l}\text { Opportunity for } \\
\text { increased } \\
\text { animal welfare, } \\
\text { that will make } \\
\text { therapeutic } \\
\text { medication } \\
\text { redundant }\end{array}$ \\
\hline $\begin{array}{l}\text { Human } \\
\text { nutrition } \\
\text { and health }\end{array}$ & $\begin{array}{l}\text { Possible risk of slightly } \\
\text { lower content of } \\
\text { secondary plant } \\
\text { metabolites; } \\
\text { importance for human } \\
\text { health is minor }\end{array}$ & - & $\begin{array}{l}\text { Risk of pesticide } \\
\text { exposure; increased } \\
\text { use of compounds } \\
\text { with identified } \\
\text { human toxicity per } \\
\text { se undesirable } \\
\text { although exposure is } \\
\text { minor }\end{array}$ & $\begin{array}{l}\text { Risk of lower } \\
\text { mineral nutrient } \\
\text { content } \\
\text { (especially in } \\
\text { cereals) }\end{array}$ & $\begin{array}{l}\text { Risk of lower content of } \\
\text { omega-3 fatty acids in } \\
\text { milk, eggs and meat; } \\
\text { importance for human } \\
\text { health is minor }\end{array}$ & $\begin{array}{l}\text { Opportunity for } \\
\text { decreased } \\
\text { fungal toxins } \\
\text { (DON) in } \\
\text { cereals, } \\
\text { opportunity for } \\
\text { lower pathogen } \\
\text { levels in } \\
\text { poultry meat }\end{array}$ \\
\hline $\begin{array}{l}\text { Farm } \\
\text { profitability }\end{array}$ & \multicolumn{6}{|c|}{ Risk or opportunity depending on the costs associated with such increases, how it affects the farmer's risk and how the revenues of the farming } \\
\hline
\end{tabular}

to design high-yielding farming systems that also care for the environment, people and animals entails a difficult value-based balancing act. Although not discussed here, farming systems also need to be resilient and, inherently, resilient systems include redundancy, which might counteract resource efficiency (Bennett et al. 2014).

In some aspects, current organic agriculture delivers benefits compared with conventional agriculture (Seufert and 
Ramankutty 2017). We note in this review that to safeguard advantages of organic farming, such as biodiversity conservation and lower nutrient losses per unit area, if strategies to increase yields are implemented, it cannot be assumed that just following current EU regulations on organic agriculture will be sufficient. Strategies to counteract possible negative consequences of yield increases will be needed at farm level and these are not currently mandatory or regulated and seldom attractive to farmers. For example, when in-field diversity decreases due to improved weed management and crops become denser due to increased fertilisation, then it will be important to implement strategies that promote biodiversity outside fields or adjacent to fields, in order to maintain biodiversity at landscape level.

As for counteracting potential increases in nutrient losses from increased fertiliser use, management strategies such as precision application of fertilisers, the use of catch crops, timely tillage and optimal design of crop rotations and nutrient filters in the landscape will be needed. The implementation of such measures, and application of nutrients at doses not exceeding optimal levels, have to be guaranteed in some way.

One of the most important yield-limiting factors in current organic crop production, if not the most important, is the availability of plant-available nutrients. At the same time, a crucial characteristic of sustainable food systems is safe recycling of nutrients from society. According to its principles, organic agriculture should rely on local resources and recycling, so ideally organic agriculture should be the driving force for the implementation of circular food systems. Unfortunately, EU regulations hinder such development through a ban on returning human wastes to land, due to contamination risks by e.g. environment pollutants and drug residues. However, in Sweden, it is possible to use certified digestate from biogas production based on food waste and slaughter waste in organic farming. This is attractive for biogas enterprises, as it is a way to increase the value of the digestate. Estimations by Spångberg (2014) show large potential of urban wastes for nutrient supply in agriculture; the $\mathrm{P}$ content in total urban wastes in Sweden was about $80 \%$ of total amount of mineral $\mathrm{P}$ used on agricultural land in Sweden 2016 (SS 2017). The return of different kinds of urban wastes, e.g. human excreta, food waste, by-products from food industry, to agricultural land, and the ability to overcome social and environmental barriers to this, need further development. We believe that organic agriculture could play an important role here; there are numerous technologies that can be applied to separate nutrients in human excreta from unwanted substances, enabling safe and trusted recycling of nutrients from food consumers back to agriculture (Bloem et al. 2017).

Apart from recycling nutrients, 'new' nutrients will also be needed to compensate for inevitable losses from fields and manure or other organic fertilisers. Currently, only legumes are allowed to provide 'new' nitrogen in organic agriculture.
However, we would encourage the organic movement to also consider (after careful evaluation) the use of mineral nitrogen fertilisers made from renewable sources (Tallaksen et al. 2015), as we believe these can comply with organic principles and offer benefits in certain cropping systems, e.g. in horticulture systems with drip irrigation.

Organic principles stipulate good care of animals and EU regulations reflect this with requirements for e.g. outdoor access, regulated slaughter ages and larger space allowances. However, current organic livestock production systems in Northern Europe commonly use high-yielding breeds, with their associated welfare problems, in systems managed according to organic regulations. The animals are not always adapted to these systems, hence introducing additional health problems (although allowing for more natural behaviours). Slightly provocatively, one can say that such organic livestock production systems are trying to "have their cake and eat it". Although it is clearly good to increase animal welfare and health in current livestock systems (and hence also improve resource efficiency and yields on herd/flock level), we ask whether in the long term it is a cul-de-sac to work on closing the yield gap between organic and conventional systems that both use the same high-yielding breeds often connected to health concerns. An alternative for the organic sector could be to implement truly alternative livestock systems, by introducing other breeds adapted to organic production conditions, e.g. more robust pig and poultry breeds better adapted to outdoor free-range rearing. Yields per animal in such systems would naturally be lower, and probably also total output on herd level, despite healthier animals. However, this could be balanced on the consumption side by dietary change through decreased livestock consumption and an increase in plantbased food, as has been identified as necessary to reach e.g. climate goals (Bajželj et al. 2014). Ultimately, feeding cereals and legumes to livestock represents a 'yield loss' in total human food calories produced. Comparison of farming systems in terms of the trade-offs between food production and environmental impact requires the use of relevant metrics and it is worth considering whether the yield of human-edible energy or protein per hectare of land might be more relevant than yield per animal (van Zanten et al. 2016).

How organic livestock production systems develop depends strongly on what consumers are willing to pay for and what policymakers are willing to support. However, based on the increased interest in sustainable foods and the flexitarian/ vegetarian trend among young consumers (Mintel 2017), partly as a reaction to 'industrialised' livestock systems, we suggest that lower-yielding but more animal-friendly organic livestock systems are likely to be more acceptable than organic systems that mimic conventional systems. Interestingly, research has shown that European consumers who buy organic foods consume more fruit, vegetables, whole grains and legumes and less red and processed meat than other consumers 
(Kesse-Guyot et al. 2013; Bradbury et al. 2014; EisingerWatzl et al. 2015). Another means to reduce the need for more food is reduction of food waste during production and processing, and by consumers (Priefer et al. 2016).

This review took its starting point in the need to raise yields in organic production. Naturally, much can be gained from better management on farms that substantially underperform in comparison with top-performing farms under the same conditions. However, one can argue that current yields on the best-performing organic farms in Northern Europe are (at least close to) 'high enough', taking into account the other outcomes from organic production (e.g. generally enhanced biodiversity, greater opportunities for animals to express natural behaviours and better profitability for farmers) and that there are greater opportunity to raise yields in areas of Africa and Asia with considerable yield gaps. Proponents of this reasoning might question the interpretation of the FAO projection of future food demand as a need to increase food production by $60 \%$ by 2050 (Alexandratos and Bruinsma 2012). On the other hand, if dietary and waste patterns are considered difficult to change, as research and practice on the promotion of healthier diets for e.g. weight reduction have shown (Douketis et al. 2005), maximising yields on all land is critically important to avoid expansion of agricultural land and associated loss of natural habitats.

In any case, if organic farming systems are to deliver substantial amounts of food to future food systems and at the same time deliver multiple other benefits, as is the ambition according to the organic principles and as increasingly expected by consumers, the organic sector and its producers, breeding companies, advisory services, farmer associations and public policy all need to focus on a broad set of goals that complement those of crop yield per hectare and yield per animal. With this review, we show that strategies to increase yields in organic agriculture can bring several synergies, but there are also apparent risks that need to be recognised and managed.

Open Access This article is distributed under the terms of the Creative Commons Attribution 4.0 International License (http:// creativecommons.org/licenses/by/4.0/), which permits unrestricted use, distribution, and reproduction in any medium, provided you give appropriate credit to the original author(s) and the source, provide a link to the Creative Commons license, and indicate if changes were made.

\section{References}

Adams DC, Salois MJ (2010) Local versus organic: a turn in consumer preferences and willingness-to-pay. Renew Agric Food Syst 25(4): 331-341. https://doi.org/10.1017/S1742170510000219

Ahlman T (2010) Organic dairy production - herd characteristics and genotype by environment interactions. Dissertation, Swedish
University of Agricultural Sciences, Uppsala. Acta Universitatis agriculturae Sueciae 1652-6880; 2010:59

Ahlman T, Berglund B, Rydhmer L, Strandberg E (2011) Culling reasons in organic and conventional dairy herds and genotype by environment interaction for longevity. J Dairy Sci 94(3):1568-1575. https:// doi.org/10.3168/jds.2010-3483

Alexandratos N, Bruinsma J (2012) World Agriculture Towards 2030/2050. The 2012 Revision. ESA Working Paper No. 12-03. Agricultural Development Economics Division. Food and Agriculture Organization of the United Nations, Rome

Appleby MC, Mench JA, Hughes BO (2004) Poultry behaviour and welfare. CABI Pub, Wallingford

Aronsson H, Torstensson G, Bergström L (2007) Leaching and crop uptake of $\mathrm{N}, \mathrm{P}$ and $\mathrm{K}$ from organic and conventional cropping systems in a clay soil. Soil Use Manag 23:71-81. https://doi.org/10. 1111/j.1475-2743.2006.00067.x

Asai M, Langer V (2014) Collaborative partnerships between organic farmers in livestock-intensive areas of Denmark. Org Agric 4:6377. https://doi.org/10.1007/s13165-014-0065-3

Askegaard M, Olesen JE, Rasmussen IA, Kristensen K (2011) Nitrate leaching from organic arable crop rotations is mostly determined by autumn field management. Agric Ecosyst Environ 142:149160. https://doi.org/10.1016/j.agee.2011.04.014

Åkesson A, Barregard L, Bergdahl IA, Nordberg GF, Nordberg M, Skerfving S (2014) Non-renal effects and the risk assessment of environmental cadmium exposure. Environ Health Perspect 122(5):431-438. https://doi.org/10.1289/ehp.1307110

Bajželj B, Richards KS, Allwood JM, Smith P, Dennis JS, Curmi E, Gilligan CA (2014) Importance of food-demand management for climate mitigation. Nat Clim Chang 4(10):924-929. https://doi. org/10.1038/nclimate2353

Beckman K (2015) Exponering för resthalter av pesticider $i$ konventionellt odlade frukter, bär och grönsaker inom EU och i tredje land jämfört med konventionellt odlade i Sverige samt ekologiskt odlade. ("Exposure for pesticide residues in conventionally grown fruits, berries and vegetables from the EU and third countries, compared to conventionally grown products from Sweden and to organically grown products, in Swedish"). Bachelor thesis. Karolinska Institutet and Stockholm Univeristy

Bedoussac L, Journet E-P, Hauggaard-Nielsen H, Naudin C, CorreHellou G, Jensen ES, Prieur L, Justes E (2015) Ecological principles underlying the increase of productivity achieved by cereal-grain legume intercrops in organic farming. A review. Agron Sust Dev 35:911-935. https://doi.org/10.1007/s13593-014-0277-7

Bennett E, Carpenter SR, Gordon LJ et al (2014) Toward a more resilient agriculture. Solut J 5(5):65-75

Benton TG, Vickery JA, Wilson JD (2003) Farmland biodiversity: is habitat heterogeneity the key? Trends Ecol Evol 18(4):182-188. https://doi.org/10.1016/s0169-5347(03)00011-9

Bindraban PS, Dimkpa C, Nagarajan L, Roy A, Rabbinge R (2015) Revisiting fertilisers and fertilisation strategies for improved nutrient uptake by plants. Biol Fert Soils 51(8):897-911. https://doi.org/10. 1007/s00374-015-1039-7

Bloem E, Albihn A, Elving J, Hermann L, Lehmann L, Sarvi M, Schaaf T, Schick J, Turtola E, Ylivainio K (2017) Contamination of organic nutrient sources with potentially toxic elements, antibiotics and pathogen microorganisms in relation to $\mathrm{P}$ fertilizer potential and treatment options for the production of sustainable fertilizers: a review. Sci Tot Environ 607-608:225-242. https://doi.org/10.1016/j. scitotenv.2017.06.274

Bommarco R, Kleijn D, Potts SG (2013) Ecological intensification: harnessing ecosystem services for food security. Trends Ecol Evol 28(4):230-238. https://doi.org/10.1016/j.tree.2012.10.012

Bradbury KE, Balkwill A, Spencer EA et al (2014) Organic food consumption and the incidence of cancer in a large prospective study of 
women in the United Kingdom. Br J Cancer 110:2321-2326. https:// doi.org/10.1038/bjc.2014.148

Burdge GC, Calder PC (2006) Dietary $\alpha$-linolenic acid and health-related outcomes: a metabolic perspective. Nutr Res Rev 19(1):26-52. https://doi.org/10.1079/NRR2005113

Chongtham IR, Bergkvist G, Watson CA, Sandström E, Bengtsson J, Öborn I (2016) Factors influencing crop rotation strategies on organic farms with different time periods since conversion to organic production. Biol Agric Hortic 33:14-27. https://doi.org/10.1080/ 01448765.2016.1174884

Clark M, Tilman D (2017) Comparative analysis of environmental impacts of agricultural production systems, agricultural input efficiency, and food choice. Environ Res Lett 12:064016. https://doi.org/10. 1088/1748-9326/aa6cd5

Connor DJ, Mínguez MI (2012) Evolution not revolution of farming systems will best feed and green the world. Glob Food Sec 1:106113. https://doi.org/10.1016/j.gfs.2012.10.004

Cooper J, Baranski M, Stewart G, Nobel-de Lange M, Bàrberi P, Fließbach A, Peigné J, Berner A, Brock C, Casagrande M, Crowley O, David C, de Vliegher A, Döring TF, Dupont A, Entz M, Grosse M, Haase T, Halde C, Hammerl V, Huiting H, Leithold G, Messmer M, Schloter M, Sukkel W, van der Heijden MGA, Willekens K, Wittwer R, Mäder P (2016) Shallow non-inversion tillage in organic farming maintains crop yields and increases soil C stocks: a meta-analysis. Agron Sustain Dev 26:22. https://doi.org/ 10.1007/s13593-016-0354-1

Crowder DW, Reganold JP (2015) Financial competitiveness of organic agriculture on a global scale. Proc Natl Acad Sci U S A 112:76117616. https://doi.org/10.1073/pnas.1423674112

Cunningham SA, Attwood SJ, Bawa KS, Benton TG, Broadhurst LM, Didham RK, McIntyre S, Perfecto I, Samways MJ, Tscharntke T, Vandermeer J, Villard MA, Young AG, Lindenmayer DB (2013) To close the yield-gap while saving biodiversity will require multiple locally relevant strategies. Agric Ecosyst Environ 173:20-27. https://doi.org/10.1016/j.agee.2013.04.007

Dahlin S, Kirchmann H, Kätterer T, Gunnarsson S, Bergström L (2005) Possibilities for improving nitrogen use from organic materials in agricultural cropping systems. Ambio 34:288-295. https://doi.org/ 10.1579/0044-7447-34.4.288

Degre A, Debouche C, Verheve D (2007) Conventional versus alternative pig production assessed by multicriteria decision analysis. Agron Sustain Dev 27(3):185-195. https://doi.org/10.1051/agro:2007004

Del Rio D, Rodriguez-Mateos A, Spencer JPE, Tognolini M, Borges G, Crozier A (2012) Dietary (poly)phenolics in human health: structures, bioavailability, and evidence of protective effects against chronic diseases. Antioxid Redox Signal 18(14):1818-1892. https://doi.org/10.1089/ars.2012.4581

Delin S, Stenberg M (2014) Effect of nitrogen fertilisation on nitrate leaching in relation to grain yield response on loamy sand in Sweden. Eur J Agron 52(Part B):291-296. https://doi.org/10.1016/ j.eja.2013.08.007

de Ponti T, Rijk B, van Ittersum MK (2012) The crop yield gap between organic and conventional agriculture. Agric Syst 108:1-9. https:// doi.org/10.1016/j.agsy.2011.12.004

Diacono M, Montemurro F (2010) Long-term effects of organic amendments on soil fertility. A review. Agron Sustain Dev 30:401-422. https://doi.org/10.1051/agro/2009040

Diehl E, Wolters V, Birkhofer K (2012) Arable weeds in organically managed wheat fields foster carabid beetles by resource- and structure-mediated effects. Arthrood Plant Interact 6:75-82. https:// doi.org/10.1007/s11829-011-9153-4

Doltra J, Lægdsmand M, Olesen JE (2011) Cereal yield and quality as affected by nitrogen availability in organic and conventional arable crop rotations: a combined modeling and experimental approach. Eur J Agron 34:83-95. https://doi.org/10.1016/j.eja. 2010.11.002
Doltra, Olesen (2013) The role of catch crops in the ecological intensification of spring cereals in organic farming under Nordic climate. Eur J Agron 44:98-108. https://doi.org/10.1016/j.eja.2012.03.006

Douketis JD, Macie C, Thabane L, Williamson DF (2005) Systematic review of long-term weight loss studies in obese adults: clinical significance and applicability to clinical practice. Int J Obes Relat Metab Disord 29(10):1153-1167. https://doi.org/10.1038/sj.ijo. 0802982

EC (2008) COMMISSION REGULATION (EC) No 889/2008 of 5 September 2008 laying down detailed rules for the implementation of Council Regulation (EC) No 834/2007 on organic production and labelling of organic products with regard to organic production, labelling and control

EC (2016) EGTOP Final Report on Organic Fertilizers and Soil Conditioners (II). https://ec.europa.eu/agriculture/organic/sites/ orgfarming/files/docs/body/final-report-egtop-on-fertilizers-2_en.pdf

EFSA (2013) Deoxynivalenol in food and feed: occurrence and exposure. EFSA J 2013(11):3379-3435

Eisinger-Watzl M, Wittig F, Heuer T, Hoffman I (2015) Customers purchasing organic food - do they live healthier? Results of the German National Nutrition Survey II. Eur J Nutr Food Saf 5(1):59-71. https://doi.org/10.9734/EJNFS/2015/12734

Ekesbo I (2015) Sommarbete för mjölkkor - hälsotillstånd, fertilitet, mjölkavkastning. ("Summer pasture for dairy cows - health, fertility, milk yield"). Svensk Veterinärtidning 8-9:11-18

Ekoweb (2017) Ekologisk livsmedelsmarknad. ("The market for organic foods."). http://www.ekoweb.nu/?p=11247\&m=2146. Accessed 14 Aug 2017

Emmerson M, Morales MB, Onate JJ et al (2016) How agricultural intensification affects biodiversity and ecosystem services. Adv Ecol Res 55:43-97. https://doi.org/10.1016/bs.aecr.2016.08.005

Engelsen Etterlin P, Morrison DA, Österberg J, Ytrehus B, Heldmer E, Ekman S (2015) Osteochondrosis, but not lameness, is more frequent among free-range pigs than confined herd-mates. Acta Vet Scand 2015:57-63. https://doi.org/10.1186/s13028-015-0154-7

Eriksson J, Matsson L, Söderström M (2010a) Tillståndet i svensk åkermark och gröda, data från 2001-2007. ("The state of Swedish arable land and crop data from 2001-2007") report 6349. Swedish Environmental Protection Agency, Stockholm, Sweden

Eriksson M, Waldenstedt L, Elwinger K, Engström B, Fossum O (2010b) Behaviour, production and health of organically reared fast-growing broilers fed low crude protein diets including different amino acid contents at start. Acta Agric Scand Sect A Anim Sci 60(2):112-124. https://doi.org/10.1080/09064702.2010.502243

Etterlin PE, Ytrehus B, Lundeheim N, Heldmer E, Österberg J, Ekman S (2014) Effects of free-range and confined housing on joint health in a herd of fattening pigs. BMC Vet Res 10(1):1-14. https://doi.org/ 10.1186/s12917-014-0208-5

EU (2014) Commission Implementing Regulation (EU) No. 354/2014 amending and correcting Regulation (EC) No. 889/2008 laying down detailed rules for the implementation of Council Regulation (EC) No. 834/2007 on organic production and labelling of organic products with regard to organic production, labelling and control

Fagerholm N, Torralba M, Burgess PJ, Plieninger T (2016) A systematic map of ecosystem services assessments around European agroforestry. Ecol Indic 62:47-65. https://doi.org/10.1016/j.ecolind.2015. 11.016

Fall N, Forslund K, Emanuelson U (2008) Reproductive performance, general health, and longevity of dairy cows at a Swedish research farm with both organic and conventional production. Livest Sci 118(1-2):11-19. https://doi.org/10.1016/j.livsci.2008.01.017

Flohre A, Fischer C, Aavik T, Bengtsson J, Berendse F, Bommarco R, Ceryngier P, Clement LW, Dennis C, Eggers S, Emmerson M, Geiger F, Guerrero I, Hawro V, Inchausti P, Liira J, Morales MB, Oñate JJ, Pärt T, Weisser WW, Winqvist C, Thies C, Tscharntke T (2011) Agricultural intensification and biodiversity partitioning in 
European landscapes comparing plant, carabids and birds. Ecol Appl 21(5):1772-1781

Flysjö A, Cederberg C, Henriksson M, Ledgard S (2012) The interaction between milk and beef production and emissions from land use change - critical considerations in life cycle assessment and carbon footprint studies of milk. J Clean Prod 28:134-142. https://doi.org/ 10.1016/j.jclepro.2011.11.046

Freibauer A, Rounsevell MDA, Smith P, Verhagen J (2004) Carbon sequestration in the agricultural soils of Europe. Geoderma 122:2-23. https://doi.org/10.1016/j.geoderma.2004.01.021

Gabriel D, Sait SM, Kunin WE, Benton TG (2013) Food production vs. biodiversity: comparing organic and conventional agriculture. J Appl Ecol 50:355-364. https://doi.org/10.1111/1365-2664.12035

Gardebroek C (2006) Comparing risk attitudes of organic and nonorganic farmers with a Bayesian random coefficient model. Eur Rev Agric Econ 33(4):485-510. https://doi.org/10.1093/erae/jbl029

Garnier J, Anglade J, Benoit M, Billen G, Puech T, Ramarson A, Passy P, Silvestre M, Lassaletta L, Trommenschlager JM, Schott C, Tallec G (2016) Reconnecting crop and cattle farming to reduce nitrogen losses to river water of an intensive agricultural catchment (seine basin, France): past, present and future. Environ Sci Policy 63:7690. https://doi.org/10.1016/j.envsci.2016.04.019

Gattinger A, Muller A, Haeni M, Skinner C, Fliessbach A, Buchmann N, Mader P, Stolze M, Smith P, Scialabba NEH, Niggli U (2012) Enhanced top soil carbon stocks under organic farming. PNAS 109:18226-18231. https://doi.org/10.1073/pnas.1209429109

Glare T, Caradus J, Gelernter W, Jackson T, Keyhani N, Köhl J, Marrone P, Morin L, Stewart A (2012) Have biopesticides come of age? Trends Biotechnol 30(5):250-258. https://doi.org/10.1016/j. tibtech.2012.01.003

Grandl F, Luzi SP, Furger M, Zeitz JO, Leiber F, Ortmann S, Clauss M, Kreuzer M, Schwarm A (2016) Biological implications of longevity in dairy cows: 1. Changes in feed intake, feeding behavior, and digestion with age. J Dairy Sci 99(5):3457-3471. https://doi.org/ 10.3168/jds.2015-10261

Gurr GM, Lu Z, Zheng X, Xu H, Zhu P, Chen G, Yao X, Cheng J, Zhu Z, Catindig JL, Villareal S, van Chien H, Cuong LQ, Channoo C, Chengwattana N, Lan LP, Hai LH, Chaiwong J, Nicol HI, Perovic DJ, Wratten SD, Heong KL (2016) Multi-country evidence that crop diversification promotes ecological intensification of agriculture. Nat Plants 2:16014

Gurr GM, Wratten SD, Landis DA, You M (2017) Habitat management to suppress pest populations: progress and prospects. Ann Rev Entom 62:91-109. https://doi.org/10.1146/annurev-ento-031616035050

Hansson I, Hamilton C, Ekman T, Forslund K (2000) Carcass quality in certified organic production compared with conventional livestock production. J Vet Med Series B Infect Dis Vet Public Health 47(2): 111-120. https://doi.org/10.1046/j.1439-0450.2000.00313.x

Hessle A, Kumm KI (2011) Use of beef steers for profitable management of biologically valuable semi-natural pastures in Sweden. J Nat Conserv 19(3):131-136. https://doi.org/10.1016/j.jnc.2010.10.002

Hoffmann R and Wivstad M (2015) Why do (don't) we buy organic food and do we get what we bargain for? EPOK-Centre for Organic Food and Farming, Swedish University of Agricultural Sciences, Uppsala. ISBN 978-91-576-9285-6

Höglund J, Dahlstrom F, Sollenberg S, Hessle A (2013) Weight gainbased targeted selective treatments (TST) of gastrointestinal nematodes in first-season grazing cattle. Vet Parasitol 196(3-4):358-365. https://doi.org/10.1016/j.vetpar.2013.03.028

Høøk Presto M (2008) Organic pig meat production. Dissertation, Swedish University of Agricultural Sciences

IFOAM (2015) Organic 3.0 for truly sustainable farming and consumption. Discussion paper by Markus Arbenz, David Gould and Christopher Stopes, based on think tanking by SOAAN and
IFOAM - Organics International and launched at the ISOFAR International Organic EXPO 2015, Goesan County

IFOAM (2005) The principles of organic agriculture. Preamble. http:// www.ifoam.bio/sites/default/files/poa_english_web.pdf. Accessed 13 Jan 2016

Jensen ES, Bedoussac L, Carlsson C, Journet E-P, Justes E, HauggardNielsen H (2015) Enhancing yields in organic crop production by eco-functional intensification. Sustain Agric Res 4(3):42-50. https:// doi.org/10.5539/sar.v4n3p42

Johansson B, Hessle A, Kumm KI (2016) Using clover/grass silage as a protein feed for dairy bull calves. Org Agric 6(1):57-63. https://doi. org/10.1007/s13165-015-0113-7

Jönsson L, Wall H, Tauson R (2011) Production and egg quality in layers fed organic diets with mussel meal. Animal 5:387-393. https://doi. org/10.1017/S1751731110001977

Jorgensen KF, Sehested J, Vestergaard M (2007) Effect of starch level and straw intake on animal performance, rumen wall characteristics and liver abscesses in intensively fed Friesian bulls. Animal 1(6):797803. https://doi.org/10.1017/s1751731107000043

Kammann C, Ippolito JA, Hagemann N, Borchard N, Cayuela ML, Estavillo JM, Fuertes-Mendizabal T, Jeffery S, Kern J, Novak J, Rasse D, Saarnio S, Schmidt HP, Spokas K, Wrage-Mönnig N (2017) Biochar as a tool to reduce the agricultural greenhouse-gas burden-knowns, unknowns and future research needs. J Environ Eng Landsc Manag 25(2):114-139. https://doi.org/10.3846/ 16486897.2017.1319375

Kabak B, Dobson AD, Var I (2006) Strategies to prevent mycotoxin contamination of food and animal feed: a review. Crit Rev Food Sci Nutr 46(8):593-619. https://doi.org/10.1080/ 10408390500436185

Kalamees R, Püssa K, Zobel K, Zobel M (2012) Restoration potential of the persistent soil seed bank in successional calcareous (alvar) grasslands in Estonia. Appl Veg Sci 15:208-218. https://doi.org/10.1111/ j.1654-109X-2011.01169.x

Kesse-Guyot E, Péneau S, Méjean C, Szabo de Edelenyi F, Galan P, Hercberg S, Lairon D (2013) Profiles of organic food consumers in a large sample of French adults: results from the Nutrinet-Sante cohort study. PLoS One 8(10):e76998. https://doi.org/10.1371/ journal.pone.0076998

Khiaosa-Ard R, Kreuzer M, Leiber F (2015) Apparent recovery of C18 polyunsaturated fatty acids from feed in cow milk: a meta-analysis of the importance of dietary fatty acids and feeding regimens in diets without fat supplementation. J Dairy Sci 98(9):6399-6414. https:// doi.org/10.3168/jds.2015-9459

Kimming M, Sundberg C, Nordberg Å, Baky A, Bernesson S, Hansson PA (2015) Replacing fossil energy for organic milk production potential biomass sources and greenhouse gas emission reductions. J Clean Prod 106:400-407. https://doi.org/10.1016/j.jclepro.2014. 03.044

Kirchmann H, Bergström L, Kätterer T, Andrén O, Andersson R (2009) Can organic crop production feed the world? In: Kirchmann H, Bergström L (eds) Organic crop production - ambitions and limitations. Springer, Dordrecht

Kirk AP, Fox SL, Entz MH (2012) Comparison of organic and conventional selection environments for spring wheat. Plant Bree 131:687694. https://doi.org/10.1111/j1439-0523.2012.02006.x

Khusro M, Andrew NR, Nicholas A (2012) Insects as poultry feed: a scoping study for poultry production systems in Australia. World's Poult Sci J 68(03):435-446. https://doi.org/10.1017/ S0043933912000554

Lacey LA, Grywacz D, Shapiro-Ilan DI, Frutos R, Brownbridge M, Goettel MS (2015) Insect pathogens as biological control agents: back to the future. J Invert Path 132:1-41. https://doi.org/10.1016/ j.jip.2015.07.009

Lammerts van Bueren ET, Jones SS, Tamm L et al (2011) The need to breed crop varieties suitable for organic farming, using wheat, 
tomato and broccoli as examples: a review. NJAS Wageningen J Life Sci 58:193-205. https://doi.org/10.1016/j.njas.2010.04.001

Läpple D, Van Rensburg T (2011) Adoption of organic farming: are there differences between early and late adoption? Ecol Econ 70:14061414. https://doi.org/10.1016/j.ecolecon.2011.03.002

Leenstra F, Maurer V, Galea F et al (2014) Laying hen performance in different production systems; why do they differ and how to close the gap? Results of discussions with groups of farmers in The Netherlands, Switzerland and France, benchmarking and model calculations. Eur Poult Sci 78. https://doi.org/10.1399/eps.2014.53

Letourneau D, van Bruggen A (2006) Crop protection in organic agriculture. Organic agriculture: a global perspective. CSIRO Publishing, Collingwood

Luoto M, Rekolainen S, Aakkula J, Pykala J (2003) Loss of plant species richness and habitat connectivity in grasslands associated with agricultural change in Finland. Ambio 32(7):447-452. https://doi.org/ 10.1579/0044-7447-32.7.447

Marchand PA (2015) Basic substances: an opportunity for approval of low-concern substances under EU pesticide regulation. Pest Manag Sci 71(9):1197-1200. https://doi.org/10.1002/ps.3997

Marles RJ (2017) Mineral nutrient composition of vegetables, fruits and grains: the context of reports of apparent historical declines. J Food Compos Anal 56:93-103. https://doi.org/10.1016/j.jfca.2016.11. 012

Mie A, Laursen K, Åberg KM et al (2014) Discrimination of conventional and organic white cabbage from a long-term field trial study using untargeted LC-MS-based metabolomics. Anal Bioanal Chem 1-13. https://doi.org/10.1007/s00216-014-7704-0

Mie A, Raun Andersen H, Gunnarsson S et al 2017 Human health implications of organic food and organic agriculture: a comprehensive review. Submitted manuscript

Mintel (2017) Food \& Drink Trends 2017. Mintel, London, UK. http:// www.mintel.com/global-food-and-drink-trends. Accessed 12 Sept 2017

Mikó P, Vida G, Rakszegi M, Lafferty J, Lorentz B, Longin CFH, Megyeri M (2017) Selection of winter durum genotypes grown under conventional and organic conditions in different European regions. Euphytica 213:169. https://doi.org/10.1007/s10681-0171953-x

Morris CE, Sands DC (2006) The breeder's dilemma - yield or nutrition? Nat Biotechnol 24(9):1078-1080. https://doi.org/10.1038/nbt09061078

Nadeau E, Arnesson A, Helander C (2015) Effects of grass silage feed value on feed intake and performance of pregnant and lactating ewes and their lambs. Grass Forage Sci 71(3):448-457. https://doi.org/10. $1111 /$ gfs. 12197

Nemes N (2009) Comparative analysis of organic and non-organic farming systems: a critical assessment of farm profitability. Food and Agriculture Organization of the United Nations, Rome

Niggli U, Schmidt J, Watson C et al (2016) Organic knowledge network arable. State-of-the-art research results and best practices. Report D.3.1; http://www.ok-neable.eu/images/OK_Net_WP3_D3.1_final. pdf. Accessed 14 Aug 2017

Nylinder J, Stenberg M, Jansson PE, Klemedtsson ÅK, Weslien P, Klemedtsson L (2011) Modelling uncertainty for nitrate leaching and nitrous oxide emissions based on a Swedish field experiment with organic crop rotation. Agric Ecosyst Environ 141(1-2):167183. https://doi.org/10.1016/j.agee.2011.02.027

Oelofse M, Stoumann Jensen L, Magid J (2013) The implication of phasing out conventional nutrient supply in organic agriculture: Denmark as a case. Org Agric 3(1):41-55. https://doi.org/10.1007/ s13165-013-0045-z

Oenema O, Oudendag D, Velthof GL (2007) Nutrient losses from manure management in the European Union. Livest Sci 112(3):261-272. https://doi.org/10.1016/j.livsci.2007.09.007
Olesen JE, Askegaard M, Rasmussen IA (2009) Winter cereal yields as affected by animal manure and green manure in organic arable farming. Eur J Agron 30(2):119-128. https://doi.org/10.1016/j.eja.2008. 08.002

Olesen JE, Hansen EM, Askegaard M, Rasmussen IA (2007) The value of catch crops and organic manures for spring barley in organic arable farming. Field Crops Res 100(2-3):168-178. https://doi. org/10.1016/j.fcr.2006.07.001

Oltenacu PA, Broom DM (2010) The impact of genetic selection for increased milk yield on the welfare of dairy cows. Anim Welf 19: $39-49$

Österman S (2003) Extended calving interval and increased milking frequency in dairy cows. Dissertation, Swedish University of Agricultural Sciences

Queiroz C, Beilin R, Folke C, Lindborg R (2014) Farmland abandonment: threat or opportunity for biodiversity conservation? A global review. Front Ecol Environ 12(5):288-296. https://doi.org/10.1890/ 120348

Patel M (2012) Effects of increasing the proportion of high-quality grass silage in the diet of dairy cows. Dissertation, Swedish University of Agricultural Sciences

Plaza-Bonilla D, Nolot J-M, Raffaillac D, Justes E (2015) Cover crops mitigate nitrate leaching in cropping systems including grain legumes: field evidence and model simulations. Agric Ecosyst Environ 212:1-12. https://doi.org/10.1016/j.agee.2015.06.014

Rodenburg TB, van Krimpen MM, de Jong IC et al (2013) The prevention and control of feather pecking in laying hens: identifying the underlying principles. Worlds Poult Sci J 69(2):361-373. https://doi. org/10.1017/S0043933913000354

Poeplau C, Don A (2015) Carbon sequestration in agricultural soils via cultivation och cover crops - a meta-analysis. Agric Ecosyst Environ 200:33-34. https://doi.org/10.1016/j.agee.2014.10.024

Poeplau C, Bolinder MA, Eriksson J, Lundblad M, Kätterer T (2015) Positive trends in organic carbon storage in Swedish agricultural soils due to unexpected socio-economic drivers. Biogeosciences 12(11):3241-3251. https://doi.org/10.5194/bg-12-3241-2015

Ponisio LC, M'Gonigle LK, Mace KC, Palomino J, de Valpine P, Kremen C (2015) Diversification practices reduce organic to conventional yield gap. Proc R Soc B 282:20141396. https://oi.org/10.1098/ rspb.2014.1396

Powlson DS, Whitmore AP, Goulding KWT (2011) Soil carbon sequestration to mitigate climate change: a critical re-examination to identify the true and the false. Eur J Soil Sci 62(1):42-55. https://doi.org/ 10.1111/j.1365-2389.2010.01342.x

Presto M, Rundgren M, Wallenbeck A (2013) Inclusion of grass/clover silage in diets of growing/finishin pigs - influence on pig time budgets and social behaviour. Acta Agric Scand Sec A Anim Sci 63(2): 84-92. https://doi.org/10.1080/09064702.2013.793734

Priefer C, Jörissen J, Bräutigam KR (2016) Food waste prevention in Europe - a cause-driven approach to identify the most relevant leverage points for action. Resour Conserv Recyc 109:155-165. https://doi.org/10.1016/j.resconrec.2016.03.004

Reganold JP, Wachter JM (2016) Organic agriculture in the twenty-first century. Nat Plants 15221. https://doi.org/10.1038/NPLANTS 2015.221

Rezaei M, Yngvesson J, Gunnarsson S, Jönsson L, Wallenbeck A (2017) Feed efficiency, growth performance, and carcass characteristics of a fast- and a slower-growing broiler hybrid fed low- or high-protein organic diets. Org Agric. https://doi.org/10.1007/s13165-017-0178-

Rodriguez-Martinez H, Hultgren J, Båge R et al (2008) Reproductive performance in high-producing dairy cows: can we sustain it under current practice? IVIS Rev Vet Med 1-23

Röös E, Sundberg C, Hansson PA (2011) Uncertainties in the carbon footprint of refined wheat products: a case study on Swedish pasta. 
Int J Life Cycle Assess 16(4):338-350. https://doi.org/10.1007/ s11367-011-0270-1

Rundlöf M, Edlund M, Smith HG (2010) Organic farming at local and landscape scales benefits plant diversity. Ecography 33(3):514-522. https://doi.org/10.1111/j.1600-0587.2009.05938.x

Salomon E, Wivstad M (2013) Rötrest från biogasanläggningar återföring av växtnäring i ekologiskt produktion. ("Digestate from biogas plants - recycling of nutrients in organic production.") EPOK-Centre for Organic Food and Farming, Swedish University of Agricultural Sciences, Uppsala. ISBN: 978-91-576-9182-8

Sapoukhina N, Paillard S, Dedryver F, de Vallavieille-Pope C (2013) Quantitative plant resistance in cultivar mixtures: wheat yellow rust as a modeling case study. New Phytol 200(3):888-897. https://doi. org/10.1111/nph.12413

SBA, SEPA, SS, SFA (2012) Hållbarhet i svenskt jordbruk 2012 ("Sustainability in Swedish agriculture 2012"). Swedish Board of Agriculture, the Swedish Environmental Protection Agency, Statistics Sweden and the Federation of Swedish Farmers. ISBN 9789161815708

Schneider MK, Lüscher G, Jeanneret P, Arndorfer M, Ammari Y, Bailey D, Balázs K, Báldi A, Choisis JP, Dennis P, Eiter S, Fjellstad W, Fraser MD, Frank T, Friedel JK, Garchi S, Geijzendorffer IR, Gomiero T, Gonzalez-Bornay G, Hector A, Jerkovich G, Jongman RHG, Kakudidi E, Kainz M, Kovács-Hostyánszki A, Moreno G, Nkwiine C, Opio J, Oschatz ML, Paoletti MG, Pointereau P, Pulido FJ, Sarthou JP, Siebrecht N, Sommaggio D, Turnbull LA, Wolfrum S, Herzog F (2014) Gains to species diversity in organically farmed fields are not propagated at the farm level. Nat Commun 5:4151. https://doi.org/10.1038/ncomms5151

Seufert V, Ramankutty N, Foley JA (2012) Comparing the yields of organic and conventional agriculture. Nature 485:229-232. https:// doi.org/10.1038/nature11069

Seufert V, Ramankutty N (2017) Many shades of gray-the contextdependent performance of organic agriculture. Sci Adv 3(3): e1602638. https://doi.org/10.1126/sciadv.1602638

Siegmeier T, Blumenstein B, Möller D (2015) Farm biogas production in organic agriculture: system implications. Agric Syst 139:196-209. https://doi.org/10.1016/j.agsy.2015.07.006

Skinner C, Gattinger A, Müller A et al (2014) Greenhouse gas fluxes from agricultural soils under organic and non-organic management - a global meta-analysis. Sci Total Environ 468-69:553-563. https://doi.org/10.1016/j.scitotenv.2013.08.098

SMED (2015) Beräkning av kväve- och fosforbelastning på vatten och hav år 2011 för uppföljning av miljökvalitetsmålet "Ingen övergödning". ("Calculation of the nitrogen and phosphorus load on waters and seas in 2011 for monitoring the environmental quality objective "Zero Eutrophication"). SMED Report 154. ISSN: 16538102

Smith P, House JI, Bustamante M, Sobocká J, Harper R, Pan G, West PC, Clark JM, Adhya T, Rumpel C, Paustian K, Kuikman P, Cotrufo MF, Elliott JA, McDowell R, Griffiths RI, Asakawa S, Bondeau A, Jain AK, Meersmans J, Pugh TAM (2016) Global change pressures on soils from land use and management. Glob Change Biol 22(3): 1008-1028. https://doi.org/10.1111/gcb.13068

Smith-Spangler C, Brandeau ML, Hunter GE, Bavinger JC, Pearson M, Eschbach PJ, Sundaram V, Liu H, Schirmer P, Stave C, Olkin I, Bravata DM (2012) Are organic foods safer or healthier than conventional alternatives? A systematic review. Ann Intern Med 157(5): 348-366. https://doi.org/10.7326/0003-4819-157-5-20120904000007

Spångberg J (2014) Recycling plant nutrients from waste and by-products. A life cycle perspective. Dissertation, Swedish University of Agricultural Sciences

Speiser B, Tamm L, Amsler T, Lambion J, Bertrand C, Hermansen A, Ruissen MA, Haaland P, Zarb J, Santos J, Shotton P, Wilcockson S, Juntharathep P, Ghorbani R, Leifert C (2006) Improvement of late blight management in organic potato production systems in Europe: field tests with more resistant potato varieties and copper-based fungicides. Biol Agric Hortic 23:393-412. https://doi.org/10.1080/ 01448765.2006.9755339

Średnicka-Tober D, Barański M, Seal C, Sanderson R, Benbrook C, Steinshamn H, Gromadzka-Ostrowska J, Rembiałkowska E, Skwarło-Sońta K, Eyre M, Cozzi G, Krogh Larsen M, Jordon T, Niggli U, Sakowski T, Calder PC, Burdge GC, Sotiraki S, Stefanakis A, Yolcu H, Stergiadis S, Chatzidimitriou E, Butler G, Stewart G, Leifert C (2016a) Composition differences between organic and conventional meat: a systematic literature review and meta-analysis. Br J Nutr 115(6):994-1011. https://doi.org/10.1017/ S0007114515005073

Średnicka-Tober D, Barański M, Seal C et al (2016b) Higher PUFA and n-3 PUFA, conjugated linoleic acid, $\alpha$-tocopherol and iron, but lower iodine and selenium concentrations in organic milk: a systematic literature review and meta- and redundancy analyses. Br J Nutr 115(6):1043-1060. https://doi.org/10.1017/S0007114516000349

SS (2016) Production of organic and non-organic farming 2015. JO 14 SM 1601. Statistics Sweden, Örebro and Swedish Board of Agriculture, Jönköping

SS (2017) Use of fertilisers and animal manure in agriculture in 2015/16. MI 30 SM 1702. Statistics Sweden, Örebro

Sundberg T, Berglund B, Rydhmer L, Strandberg E (2009) Fertility, somatic cell count and milk production in Swedish organic and conventional dairy herds. Livest Sci 126(1-3):176-182. https://doi.org/ 10.1016/j.livsci.2009.06.022

Sundberg T, Rydhmer L, Fikse F, Berglund B, Strandberg E (2010) Genotype by environment interaction of Swedish dairy cows in organic and conventional production systems. Acta Agric Scand Sec A Anim Sci 60(2):65-73. https://doi.org/10.1080/09064702. 2010.496003

Tallaksen J, Bauer F, Hulteberg C, Reese M, Ahlgren S (2015) Nitrogen fertilizers manufactured using wind power : greenhouse gas and energy balance of community-scale ammonia production. J Clean Prod 107:626-635. https://doi.org/10.1016/j.jclepro.2015.05.130

Thapa S, Hinrichsen LK, Brenninkmeyer C, Gunnarsson S, Heerkens JLT, Verwer C, Niebuhr K, Willett A, Grilli G, Thamsborg SM, Sørensen JT, Mejer H (2015) Prevalence and magnitude of helminth infections in organic laying hens (Gallus gallus domesticus) across Europe. Vet Parasitol 214(1-2):118-124. https://doi.org/10.1016/j. vetpar.2015.10.009

Torstensson G, Aronsson H, Bergström L (2006) Nutrient use efficiencies of organic and conventional cropping systems in Sweden. Agron J 98:603-615. https://doi.org/10.2134/agronj2005.0224

Treutter D (2010) Managing phenol contents in crop plants by phytochemical farming and breeding - visions and constraints. Int J Mol Sci 21(3):807-857. https://doi.org/10.3390/ijms11030807

Tschumi M, Albrecht M, Bärtschi C, Collatz J, Entling M, Jacot K (2016) Perennial, species-rich wildflower strips enhance pest control and crop yield. Agric Ecos Environ 220:97-103. https://doi.org/10. 1016/j.agee.2016.01.001

Tuck SL, Winqvist C, Mota F, Ahnström J, Turnbull LA, Bengtsson J (2014) Land-use intensity and the effects of organic farming on biodiversity: a hierarchical meta-analysis. J Appl Ecol 51:746755. https://doi.org/10.1111/1365-2664.12219

von Keyserlingk MAG, Hotzel MJ (2015) The ticking clock: addressing farm animal welfare in emerging countries. J Agric Environ Earth 28(1):179-195. https://doi.org/10.1007/s10806-014-9518-7

van Krimpen MM, Leenstra F, Maurer V, Bestman M (2016) How to fulfill EU requirements to feed organic laying hens $100 \%$ organic ingredients. J Appl Poult Res 25:229-138. https://doi.org/10.3382/ $\mathrm{japr} / \mathrm{pfv} 048$

van Lenteren JC (2012) The state of commercial augmentative biological control: plenty of natural enemies, but a frustrating lack of uptake. BioControl 57(1):2-20. https://doi.org/10.1007/s10526-011-9395-1 
van Zanten HHE, Mollenhorst H, Klootwijk CW, van Middelaar CE, de Boer IJM (2016) Global food supply: land use efficiency of livestock systems. Int J Life Cycle Assess 21(5):747-758. https://doi. org/10.1007/s11367-015-0944-1

Van Wagenberg C, De Haas Y, Hogeveen H et al (2017) Animal board invited review: comparing conventional and organic livestock production systems on different aspects of sustainability. Animal 11(10):1839-1851. https://doi.org/10.1017/S175173111700115

VKM (2014) Part II: Animal health and welfare in Norway Comparison of organic and conventional food and food production (Opinion of the Panel on Animal Health and Welfare and the Steering Committee of the Norwegian Scientific Committee for Food Safety) Vol. 11-007-2-Final, Oslo

VS (2017) Husdjursstatistik 2017. (“Cattle statistics 2017”). Växa Sverige, Uppsala

Wallenbeck A (2009) Pigs for organic production - studies of sow behaviour, piglet-production and $\mathrm{GxE}$ interactions for performance. Dissertation. Swedish University of Agricultural Sciences, Uppsala, Acta Universitatis agriculturae Sueciae 1652-6880; 2009:37

Wallenbeck A (2012) Foder till grisar i ekologisk produktion. ("Feed to Pigs in Organic Production") EPOK-Centre for Organic Food and Farming, Swedish University of Agricultural Sciences, Uppsala. ISBN: 978-91-576-9084-5

Wallenbeck A, Gustafson G, Rydhmer L (2009) Sow performance and maternal behaviour in organic and conventional herds. Acta Agric Scand Sec A Anim Sci 59(3):281-191. https://doi.org/10.1080/ 09064700903307824

Wallenbeck A, Rundgren M, Presto M (2014) Inclusion of grass/clover silage in diets to growing/finishing pigs - Influence on performance and carcass quality. Acta Agric Scand Sec A Anim Sci 64(3):145153. https://doi.org/10.1080/09064702.2015.1006668

Wallenbeck A, Wilhelmsson S, Jönsson L, Gunnarsson S, Yngvesson Y (2017) Behaviour in one fast-growing and one slower-growing broiler (Gallus gallus domesticus) hybrid fed a high- or a lowprotein diet during a 10-week rearing period. Acta Agric Scand
Sec A Anim Sci 66(3):168-176. https://doi.org/10.1080/ 09064702.2017 .1303081

Watson CA, Bengtsson H, Løes A-K, Myrbeck A, Salomon E, Schroder J, Stockdale EA (2002) A review of farm-scale nutrient budgets for organic farms as a tool for management of soil fertility. Soil Use Manag 18:264-273. https://doi.org/10.1111/j.1475-2743.2002. tb00268.x

Webb J, Sorensen P, Velthof G et al. (2013) An assessment of the variation of manure nitrogen efficiency throughout Europe and an appraisal of means to increase manure-N efficiency. In: Sparks D. L. (eds) Adv Agron Vol 119:371-442. https://doi.org/10.1016/B978-012-407247-3.00007-X

Weibull AC, Östman Ö (2003) Species composition in agroecosystems: the effect of landscape, habitat, and farm management. Basic Appl Ecol 4:349-361. https://doi.org/10.1078/1439-1791-00173

Wierup M, Wahlström H, Lahti E, Eriksson H, Jansson DS, Odelros Å, Ernholm L (2017) Occurrence of Salmonella spp.: a comparison between indoor and outdoor housing of broilers and laying hens. Acta Vet Scand 59(1):13. https://doi.org/10.1186/s13028-0170281-4

Wiesler F (2012) Nutrition and quality Marschner's mineral nutrition of higher plants, 3rd edn. Academic Press, San Diego

Winqvist C, Ahnström J, Bengtsson J (2012) Effects of organic farming on biodiversity and ecosystem services: taking landscape complexity into account. Ann New York Acad Sci 1249:191-203. https:// doi.org/10.1111/j.1749-6632.2011.06413.x/abstract

Wolfe MS, Baresel JP, Desclaux D, Goldringer I, Hoad S, Kovacs G, Löschenberger F, Miedaner T, Østergård H, Lammerts van Bueren ET (2008) Developments in breeding cereals for organic agriculture. Euphytica 163:323-346. https://doi.org/10.1007/s10681-008-9690-9

Wollman I and Möller K (2015) Assessment of alternative phosphorus fertilisers for organic farming: Sewage precipitation products. Fact sheet, Improve-P. http://orgprints.org/28142. Accessed 10 June 2016

Woods VB, Fearon AM (2009) Dietary sources of unsaturated fatty acids for animals and their transfer into meat, milk and eggs: a review. Livest Sci 226(1-3):2-20. https://doi.org/10.1016/j.livsci.2009.07.002 